\title{
Inorganic carbon acquisition in red tide dinoflagellates
}

\author{
BJÖRN ROST ${ }^{1}$, KLAUS-UWE RICHTER $^{1}$, ULF RIEBESELL $^{2}$ \& PER JUEL HANSEN ${ }^{3}$ \\ ${ }^{1}$ Alfred Wegener Institute for Polar and Marine Research, Am Handelshafen 12, 27515 Bremerhaven, Germany, ${ }^{2}$ Leibniz \\ Institute of Marine Sciences, Duesternbrooker Weg 20, 24105 Kiel, Germany, and ${ }^{3}$ Marine Biological Laboratory, University \\ of Copenhagen, Strandpromenaden 5, 3000 Helsing $\varnothing$, Denmark
}

\begin{abstract}
Carbon acquisition was investigated in three marine bloomforming dinoflagellates - Prorocentrum minimum, Heterocapsa triquetra and Ceratium lineatum. In vivo activities of extracellular and intracellular carbonic anhydrase (CA), photosynthetic $\mathrm{O}_{2}$ evolution, $\mathrm{CO}_{2}$ and $\mathrm{HCO}_{3}^{-}$uptake rates were measured by membrane inlet mass spectrometry (MIMS) in cells acclimated to low $\mathrm{pH}(8.0)$ and high $\mathrm{pH}$ (8.5 or 9.1). A second approach used short-term ${ }^{14} \mathrm{C}$ disequilibrium incubations to estimate the carbon source utilized by the cells. All three species showed negligible extracellular CA (eCA) activity in cells acclimated to low pH and only slightly higher activity when acclimated to high pH. Intracellular CA (iCA) activity was present in all three species, but it increased only in $P$. minimum with increasing $\mathrm{pH}$. Half-saturation concentrations $\left(K_{1 / 2}\right)$ for photosynthetic $\mathrm{O}_{2}$ evolution were low compared to ribulose 1,5-bisphosphate carboxylase/oxygenase (Rubisco) kinetics. Moreover, apparent affinities for inorganic carbon (Ci) increased with increasing $\mathrm{pH}$ in the acclimation, indicating the operation of an efficient $\mathrm{CO}_{2}$ concentration mechanism (CCM) in these dinoflagellates. Rates of $\mathrm{CO}_{2}$ uptake were comparably low and could not support the observed rates of photosynthesis. Consequently, rates of $\mathrm{HCO}_{3}^{-}$uptake were high in the investigated species, contributing more than $80 \%$ of the photosynthetic carbon fixation. The affinity for $\mathrm{HCO}_{3}{ }^{-}$and maximum uptake rates increased under higher $\mathrm{pH}$. The strong preference for $\mathrm{HCO}_{3}^{-}$was also confirmed by the ${ }^{14} \mathrm{C}$-disequilibrium technique. Modes of carbon acquisition were consistent with the ${ }^{13} \mathrm{C}$-fractionation pattern observed and indicated a strong species-specific difference in leakage. These results suggest that photosynthesis in marine dinoflagellates is not limited by $\mathrm{Ci}$ even at high $\mathrm{pH}$, which may occur during red tides in coastal waters.
\end{abstract}

Key-words: Ceratium lineatum; Heterocapsa triquetra; Prorocentrum minimum; ${ }^{13} \mathrm{C}$ fractionation; $\mathrm{CO}_{2}$ concentrating mechanism; $\mathrm{CO}_{2}$ uptake; $\mathrm{HCO}_{3}^{-}$uptake; $\mathrm{pH}$; photosynthesis.

\section{INTRODUCTION}

Inorganic carbon $(\mathrm{Ci})$ acquisition has been suggested to play an important role in marine phytoplankton ecology

Correspondence: Björn Rost.e-mail: brost@awi-bremerhaven.de

810 and evolution (Tortell 2000; Rost et al. 2003; Giordano, Beardall \& Raven 2005). Despite the relatively high concentrations of dissolved inorganic carbon (DIC) in marine environments, phytoplankton cells have to invest considerable resources in carbon acquisition to allow for high rates of photosynthesis. This circumstance is mainly caused by the primary carboxylating enzyme, ribulose 1,5-bisphosphate carboxylase/oxygenase (Rubisco), which is restricted to $\mathrm{CO}_{2}$ for carbon fixation. This highly conserved enzyme is characterized by a low affinity for its substrate $\mathrm{CO}_{2}$, slow maximum specific turnover rate and susceptibility to a competing reaction with $\mathrm{O}_{2}$. The latter reaction initiates the process of photorespiration, which further lowers the rate of carbon fixation.

Under present atmospheric conditions (i.e. low $\mathrm{CO}_{2}$ and high $\mathrm{O}_{2}$ levels), the catalytic inefficiency of Rubisco imposes restrictions on the carbon assimilation of all photoautotrophs. This is particularly true for algae as $\mathrm{CO}_{2}$ availability in water is further reduced, owing to slow $\mathrm{CO}_{2}$ diffusion rate, slow conversion rate between $\mathrm{HCO}_{3}^{-}$and $\mathrm{CO}_{2}$ and low $\mathrm{CO}_{2}$ concentrations under alkaline conditions. To avoid carbon limitation in photosynthesis, algae developed mechanisms to enhance intracellular $\mathrm{CO}_{2}$ concentration at the site of carboxylation. These $\mathrm{CO}_{2}$ concentrating mechanisms (CCMs) involve active uptake of $\mathrm{CO}_{2}$ and/or $\mathrm{HCO}_{3}{ }^{-}$, as well as of the enzyme carbonic anhydrase (CA), which accelerates the otherwise slow conversion rate between $\mathrm{HCO}_{3}{ }^{-}$and $\mathrm{CO}_{2}$. In addition to an effective uptake of $\mathrm{Ci}$, it is equally necessary for microalgae to minimize $\mathrm{Ci}$ losses via leakage, a risk that increases with increasing accumulation of $\mathrm{Ci}$. Phytoplankton species differ in efficiency and regulation of their CCMs (e.g. Burkhardt et al. 2001; Beardall \& Giordano 2002; Rost et al. 2003) and in the catalytic efficiency of their Rubisco (Badger et al. 1998; Tortell 2000). As a consequence, some species are $\mathrm{CO}_{2}$ sensitive in their photosynthesis, whereas other species are rate-saturated even under low ambient $\mathrm{CO}_{2}$ concentrations.

Dinoflagellates are a diverse and abundant group of protists with complex interactions in the food web. They can form so-called 'red tides' in coastal waters, a name that was given because of the changes in water colour observed at times. Such mass development has enormous ecological implications, especially because some dinoflagellates are known to produce various toxins. Despite its ecological and economic importance, relatively little research on photosynthesis and carbon acquisition has been done on this group (Giordano et al. 2005). However, this task is very 
intriguing because most dinoflagellates seem to possess the form II Rubisco, featuring one of the lowest affinities for $\mathrm{CO}_{2}$ and a high sensitivity for $\mathrm{O}_{2}$ (Badger et al. 1998). Only Rubiscos of cyanobacteria shows similarly low substratespecificity factors $\left(\mathrm{S}_{\mathrm{rel}}\right)$, a parameter describing the selectivity of the carboxylation over oxygenation reaction of Rubisco.

Laboratory experiments demonstrated the capability of dinoflagellates to accumulate $\mathrm{Ci}$ relative to ambient concentrations during photosynthesis. Accumulation factors varied between 5- and 70-fold, depending on the species and growth condition (Berman-Frank, Erez \& Kaplan 1998; Leggat, Badger \& Yellowlees 1999; Nimer, Brownlee $\&$ Merrett 1999). Mechanisms that enhance the intracellular $\mathrm{CO}_{2}$ concentration require active uptake of either or both $\mathrm{CO}_{2}$ and $\mathrm{HCO}_{3}{ }^{-}$. Studies on zooxanthellae isolates from corals found that $\mathrm{HCO}_{3}{ }^{-}$is the carbon species mostly taken up (Goiran et al. 1996). In isolates from giant clams, the preferred carbon source changed from $\mathrm{CO}_{2}$ to $\mathrm{HCO}_{3}^{-}$ after incubation in seawater for $2 \mathrm{~d}$ (Leggat et al. 1999). A recent study on the free-living dinoflagellates Amphidinium carterae and Heterocapsa oceanica found no evidence of $\mathrm{HCO}_{3}^{-}$use (Dason, Huertas \& Colman 2004). Based on their findings, it was suggested that these species are $\mathrm{CO}_{2}$ limited in their natural environment, even at airequilibrated $\mathrm{CO}_{2}$ values.

In coastal waters, photosynthetic activity during dinoflagellate blooms may result in elevated $\mathrm{pH}$ levels in the photic zone (Hansen 2002; Hinga 2002). These dinoflagellate blooms last for extended periods of time (several weeks) and the $\mathrm{pH}$ level often reaches values above 9 - occasionally up to 9.75 (Hansen 2002). Such high $\mathrm{pH}$ levels may cause a succession of phytoplankton species, as some species are more sensitive to elevated $\mathrm{pH}$ than others. While species growth in some dinoflagellates is already affected above $\mathrm{pH} 8.4$, other species grow unaffected until $\mathrm{pH}$ values reach 10.2 (see Hansen 2002). The reason for this large difference in $\mathrm{pH}$ tolerance among dinoflagellates is unknown, but a number of different suggestions have been put forward, including $\mathrm{Ci}$ limitation (e.g. Hansen 2002). At high pH, the concentration of DIC is reduced owing to its removal by the algae. As a result of concomitant changes in the chemical speciation, a greater proportion of the $\mathrm{Ci}$ pool will be in the form of $\mathrm{CO}_{3}{ }^{2-}$, which may be unavailable for algae. More importantly, increasing $\mathrm{pH}$ causes the $\mathrm{CO}_{2}$ concentration to drop far below airequilibrated $\mathrm{CO}_{2}$ values. Thus, species which rely mostly on $\mathrm{CO}_{2}$ as a $\mathrm{Ci}$ source will be less competitive at high $\mathrm{pH}$.

In the present study, we investigated modes of carbon acquisition of three marine dinoflagellates acclimated to low and high $\mathrm{pH}$. Our test organisms, Prorocentrum minimum, Heterocapsa triquetra and Ceratium lineatum, are all bloom-forming dinoflagellates with different levels of tolerance to high $\mathrm{pH}$. In each species, we examined photosynthetic $\mathrm{O}_{2}$ evolution and quantified $\mathrm{CO}_{2}$ and $\mathrm{HCO}_{3}^{-}$ fluxes across the plasmalemma during steady-state photosynthesis using membrane inlet mass spectrometry (MIMS) (Badger, Palmqvist \& Yu 1994). As a second independent technique, short-term ${ }^{14} \mathrm{C}$-disequilibrium experiments were conducted to estimate the carbon source being utilized by the cells. Activities of extracellular and intracellular CA were determined by monitoring ${ }^{18} \mathrm{O}$ exchange from doubly labelled ${ }^{13} \mathrm{C}^{18} \mathrm{O}_{2}$ (Palmqvist, $\mathrm{Yu}$ \& Badger 1994). In addition, we took samples to analyse the isotopic composition of particulate organic carbon (POC), which allowed us to calculate ${ }^{13} \mathrm{C}$ fractionation $\left(\varepsilon_{\mathrm{P}}\right)$ of the cells.

\section{MATERIALS AND METHODS}

\section{Culture conditions and sampling}

P. minimum, H. triquetra and C. lineatum (isolates from the Marianger Fjord, culture collection of the Marine Biological Laboratory in Helsing $\varnothing$, Denmark) were grown at $15^{\circ} \mathrm{C}$ in $0.2 \mu \mathrm{m}$ filtered and unbuffered seawater (salinity 34 ), which was enriched with nutrients according to an $\mathrm{f} / 2$ medium (Guillard \& Ryther 1962). Dilute batch cultures were grown in $2.4 \mathrm{~L}$ borosilicate bottles under a light-dark cycle of $16: 8 \mathrm{~h}$ and an incident photon flux density (PFD) of $150 \mu \mathrm{mol}$ photons $\mathrm{m}^{-2} \mathrm{~s}^{-1}$. A light-dark cycle was chosen because continuous light caused much lower rates for photosynthesis and $\mathrm{Ci}$ uptake in marine phytoplankton of different taxa (Rost, Riebesell \& Sültemeyer 2006).

In the cultures, $\mathrm{pH}$ was adjusted by addition of $\mathrm{HCl}$ or $\mathrm{NaOH}$ to a lower $\mathrm{pH}$ of 8.0 and a higher $\mathrm{pH}$ of 8.5 or 9.1 . This corresponds to $\mathrm{CO}_{2}$ concentrations of 22.6, 7.1 and $1.4 \mu \mathrm{mol} \mathrm{CO} \mathrm{CO}_{2} \mathrm{~L}^{-1}$, respectively. The upper $\mathrm{pH}$ was chosen based on the $\mathrm{pH}$-dependence of growth of the respective species (i.e. the highest $\mathrm{pH}$ at which cell division remains unaltered). This was 9.1 for P. minimum and H. triquetra; as for C. lineatum, growth was already affected above 8.5 (Hansen 2002). Cultures were not bubbled with air that contain different $\mathrm{CO}_{2}$ partial pressures because dinoflagellates are known to be negatively affected by turbulence. Daily dilution with fresh media ensured that the $\mathrm{pH}$ level remained constant ( \pm 0.1 units) and that the cells stayed in the mid-exponential growth phase. Growth rates were about $0.45 \mathrm{~d}^{-1}$ in P. minimum, $0.55 \mathrm{~d}^{-1}$ in H. triquetra and $0.35 \mathrm{~d}^{-1}$ in $C$. lineatum, both at low and high $\mathrm{pH}$. Cell concentrations in the cultures ranged between 500 and 3000 cells $\mathrm{mL}^{-1}$.

After at least $5 \mathrm{~d}$ of acclimation to the respective conditions and within 3-7 $\mathrm{h}$ after the beginning of the photoperiod, cells were concentrated by gentle filtration over an $8 \mu \mathrm{m}$ filter. The culture media was hereby stepwise exchanged with the respective buffered assay media. In case of assays for CA activity or Ci fluxes by MIMS, cells were transferred into a $\mathrm{CO}_{2}$-free $\mathrm{f} / 2$ medium, buffered with 2-[4-(2-Hydroxyethyl)-1-piperazinyl]-ethanesulfonic acid (HEPES, 50 mmol L ${ }^{-1}, \mathrm{pH}$ 8.0). Short-term ${ }^{14} \mathrm{C}$ incubations required cells to be transferred into an $\mathrm{f} / 2$ medium, buffered with N,N-Bis(2-hydroxyethyl) glycerine (BICINE, $20 \mathrm{mmol} \mathrm{L}^{-1}, \mathrm{pH} 8.5$ ).

Samples for the determination of Chl $a$ concentration were taken after the measurements by centrifuging an 
aliquot of the cell suspension. Pellets were stored at $-80^{\circ} \mathrm{C}$ until they were extracted in $1 \mathrm{~mL}$ of acetone (overnight in darkness, at $-28^{\circ} \mathrm{C}$ ) and analysed by high-performance liquid chromatography (HPLC). Chl $a$ concentrations in the assays ranged from 0.05 to $0.7 \mu \mathrm{g} \mathrm{mL}^{-1}$.

\section{Determination of CA activity}

CA activity was determined from the ${ }^{18} \mathrm{O}$-depletion of doubly labelled ${ }^{13} \mathrm{C}^{18} \mathrm{O}_{2}$ in water caused by several $\mathrm{CO}_{2}$ and $\mathrm{HCO}_{3}{ }^{-}$hydration and dehydration steps (Silvermann 1982). This mass spectrometric procedure allows the determination of CA activity from intact cells under conditions similar to those during growth and differentiates between extracellular CA (eCA) and intracellular CA (iCA) activity (e.g. Rost et al. 2003).

All measurements were carried out in an $8 \mathrm{~mL}$ thermostated cuvette, which was attached to a sectorfield multicollector mass spectrometer (IsoPrime; GV Instruments, Manchester, UK) via a gas-permeable membrane [polytetrafluoroethylene (PTFE), $0.01 \mathrm{~mm}$ ] inlet system. Changes in the ion-beam intensities corresponding to concentrations of the $\mathrm{CO}_{2}$ isotopomers ${ }^{13} \mathrm{C}^{18} \mathrm{O}^{18} \mathrm{O}(\mathrm{m} / \mathrm{z}=49),{ }^{13} \mathrm{C}^{18} \mathrm{O}^{16} \mathrm{O}(\mathrm{m} /$ $\mathrm{z}=47)$ and ${ }^{13} \mathrm{C}^{16} \mathrm{O}^{16} \mathrm{O}(\mathrm{m} / \mathrm{z}=45)$ were recorded continuously and calculated as:

$$
\begin{aligned}
{ }^{18} \mathrm{O} \log (\text { enrichment }) & =\log \frac{\left({ }^{13} \mathrm{C}^{18} \mathrm{O}_{2}\right) \times 100}{{ }^{13} \mathrm{CO}_{2}} \\
& =\log \frac{(49) \times 100}{45+47+49} .
\end{aligned}
$$

Measurements of eCA and iCA activities were performed in the $\mathrm{CO}_{2}$-free $\mathrm{f} / 2$ medium, buffered with HEPES-NaOH $\left(50 \mathrm{mmol} \mathrm{L}{ }^{-1}, \mathrm{pH} 8.0\right)$ at $15^{\circ} \mathrm{C}$. All assays were carried out in the dark, unless stated otherwise. $\mathrm{NaH}^{13} \mathrm{C}^{18} \mathrm{O}_{3}$ was added to a final concentration of $1 \mathrm{mmol} \mathrm{L}^{-1}$ and the uncatalysed rate of ${ }^{18} \mathrm{O}$ loss was recorded for at least $8 \mathrm{~min}$. Afterwards, $50-150 \mu \mathrm{L}$ of cells suspension were added to yield a final Chl $a$ concentration of $0.1-0.5 \mu \mathrm{g} \mathrm{mL}^{-1}$. Representative results for such an assay are given in Fig. 1. For calculation of eCA activity, the linear rate of decrease in ${ }^{18} \mathrm{O}$-atom fraction after the addition of the sample $\left(S_{2}\right)$ was compared to the non-catalysed decline $\left(S_{1}\right)$ and normalized on a Chl $a$ basis (Badger \& Price 1989):

$U=\frac{\left(S_{2}-S_{1}\right) \times 100}{S_{1} \times \operatorname{mg~Chl~} a}$.

iCA activity was estimated from the rapid decline in $\log$ (enrichment) upon injection of cells and calculated according to Palmqvist et al. (1994). In this assay, a membrane-impermeable inhibitor of CA [dextran-bound sulfonamide (DBS), Synthelec AB, Lund, Sweden] was added prior to the injection of cells to a final concentration of $50 \mu \mathrm{mol} \mathrm{L}{ }^{-1}$. Subsequent to the iCA measurements, light was switched on $\left(300 \mu \mathrm{mol}\right.$ photons $\left.\mathrm{m}^{-2} \mathrm{~s}^{-1}\right)$ to monitor light-induced changes in the ${ }^{18} \mathrm{O}$ exchange.

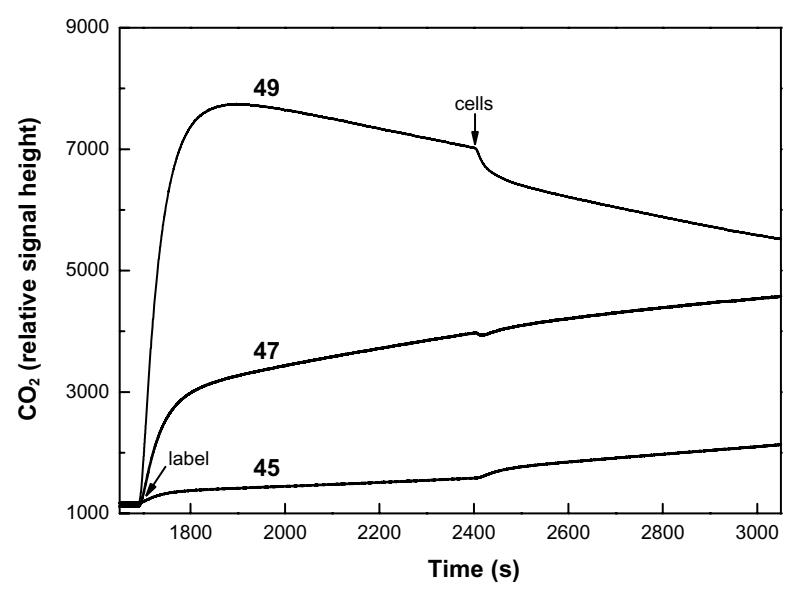

Figure 1. Example for a mass spectrometric carbonic anhydrase (CA) assay showing changes in the relative concentrations of the $\mathrm{CO}_{2}$ isotopes ${ }^{13} \mathrm{C}^{18} \mathrm{O}_{2}(\mathrm{~m} / \mathrm{z}=49),{ }^{13} \mathrm{C}^{16} \mathrm{O}^{18} \mathrm{O}(\mathrm{m} / \mathrm{z}=47)$ and ${ }^{13} \mathrm{CO}_{2}$ $(\mathrm{m} / \mathrm{z}=45)$ upon the addition of $\mathrm{NaH}^{13} \mathrm{C}^{18} \mathrm{O}_{3}\left(1 \mathrm{mmol} \mathrm{L}^{-1}\right)$. The uncatalysed rate of ${ }^{18} \mathrm{O}$ loss was recorded for about $8 \mathrm{~min}$ followed by the addition of cells. This graph shows an example for Prorocentrum minimum acclimated to $\mathrm{pH} 9.1$.

\section{Isotope-disequilibrium experiments}

The ${ }^{14} \mathrm{C}$-disequilibrium technique makes use of the transient isotopic disequilibrium upon an acidic ${ }^{14} \mathrm{C}$ spike into cell suspension at high $\mathrm{pH}$ to determine whether $\mathrm{CO}_{2}$ or $\mathrm{HCO}_{3}{ }^{-}$is the preferred carbon species for photosynthesis (Espie \& Colman 1986; Elzenga, Prins \& Stefels 2000). In the present study we largely followed the protocol described by Tortell \& Morel (2002), with a few modifications.

Cells were transferred into a cuvette ( $4 \mathrm{~mL}$ volume) containing an $\mathrm{f} / 2$ medium buffered at $\mathrm{pH} 8.5$ (BICINE-NaOH, $20 \mathrm{mmol} \mathrm{L}^{-1}$ ) at $15^{\circ} \mathrm{C}$. After pre-incubation to $300 \mu \mathrm{mol}$ photons $\mathrm{m}^{-2} \mathrm{~s}^{-1}$ for $6 \mathrm{~min}$, a $20 \mu \mathrm{Ci}{ }^{14} \mathrm{C}$ spike of $\mathrm{pH} 7.0$ [CFA3 (Amersham Pharmacia Biotech, Cardiff, UK) in HEPES, $50 \mathrm{mmol} \mathrm{L}^{-1}$ ] was injected into the cell suspension. To examine the importance of eCA, incubations were run without and with DBS $\left(50 \mu \mathrm{mol} \mathrm{L}^{-1}\right)$. After the injection of the ${ }^{14} \mathrm{C}$ spike, $200 \mu \mathrm{L}$ subsamples were withdrawn at short intervals and dispensed into $1.5 \mathrm{~mL}$ of $\mathrm{HCl}(6 \mathrm{~N})$. To remove residual inorganic ${ }^{14} \mathrm{C}$ that had not been fixed, samples were purged with air for at least $3 \mathrm{~h}$. Afterwards, $10 \mathrm{~mL}$ scintillation cocktail (Ultima Gold AB, PerkinElmer, Boston, MA, USA) was added to the vials and ${ }^{14} \mathrm{C}$ was measured by standard liquid scintillation procedures. To correct for small residual inorganic ${ }^{14} \mathrm{C}$, blanks consisting of spike added to cell-free buffer were measured.

For quantitative interpretation of ${ }^{14} \mathrm{C}$-disequilibrium data we fitted the data according to equations derived from Espie \& Colman (1986) and Elzenga et al. (2000). Briefly, the instantaneous rate of $\mathrm{Ci}$ uptake is equal to the sum of $\mathrm{CO}_{2}$ and $\mathrm{HCO}_{3}^{-}$uptake at any time and is given by (Elzenga et al. 2000):

$$
d\left(D P M_{\mathrm{t}}\right) / d t=V_{\mathrm{CO}_{2}} \times S A_{\mathrm{CO}_{2} \mathrm{t}} \times V_{\mathrm{HCO}_{3}{ }^{-}} \times S A_{\mathrm{HCO}_{3}{ }^{-} \mathrm{t}}
$$


where $d\left(D P M_{\mathrm{t}}\right) / d t$ is the instantaneous rate of Ci uptake at time $t$ and $V_{\mathrm{CO}_{2}}$ and $V_{\mathrm{HCO}_{3}^{-}}$are the rates of uptake for $\mathrm{CO}_{2}$ and $\mathrm{HCO}_{3}^{-}$, respectively. The differences in $\mathrm{CO}_{2-}$ and $\mathrm{HCO}_{3}{ }^{-}$-specific activities affect the instantaneous rate of ${ }^{14} \mathrm{C}$ uptake from these species. $S A_{\mathrm{CO}_{2} \mathrm{t}}$ and $S A_{\mathrm{HCO}_{3}^{-}}$are the specific activities of $\mathrm{CO}_{2}$ and $\mathrm{HCO}_{3}{ }^{-}$, respectively. Changes in $\mathrm{SA}$ of $\mathrm{CO}_{2}$ and $\mathrm{HCO}_{3}^{-}$with time are given by (Elzenga et al. 2000):

$$
\begin{aligned}
& S A_{\mathrm{CO}_{2} \mathrm{t}}=S A_{\mathrm{DIC}}+\Delta S A_{\mathrm{CO}_{2}} \times e^{-\alpha_{1} \mathrm{t}} \text { and } \\
& S A_{\mathrm{HCO}_{3}{ }^{-\mathrm{t}}}=S A_{\mathrm{DIC}}+\Delta S A_{\mathrm{HCO}_{3}^{-}} \times e^{-\alpha_{2} \mathrm{t}}
\end{aligned}
$$

where $S A_{\text {DIC }}$ is the specific activity of the total DIC at equilibrium, $\triangle S A$ is the difference between the initial and equilibrium values in the specific activity of $\mathrm{CO}_{2}$ and $\mathrm{HCO}_{3}^{-}$, and $\alpha_{1}$ and $\alpha_{2}$ are the temperature, salinity and $\mathrm{pH}-$ dependent first-order rate constants for $\mathrm{CO}_{2}$ and $\mathrm{HCO}_{3}^{-}$, respectively, as described by Espie \& Colman (1986). Our experimental constants were: temperature $=15^{\circ} \mathrm{C}$; salinity $=34 ; \mathrm{pH}$ value $=8.5 ; \alpha_{1}=0.0272 ;$ and $\alpha_{2}=0.0315 . \alpha_{1}$ and $\alpha_{2}$ were determined by adjusting temperature and salinity corrections acquired from Johnson (1982). The integrated accumulation of ${ }^{14} \mathrm{C}$ has been modified from Elzenga et al. (2000) by introducing $f$ as the proportion of $\mathrm{HCO}_{3}^{-}$ relative to net $\mathrm{Ci}$ fixation:

$$
\begin{aligned}
D P M_{\mathrm{t}}= & V(1-\mathrm{f}) \times\left[\alpha_{1} \mathrm{t}+\left(\Delta S A_{\mathrm{CO}_{2}} / S A_{\mathrm{DIC}}\right) \times\right. \\
& \left.\left(1-e^{-\alpha_{1} \mathrm{t}}\right)\right] / \alpha_{1}+V(\mathrm{f}) \times\left[\alpha_{2} \mathrm{t}+\right. \\
& \left.\left(\Delta S A_{\mathrm{HCO}_{3}^{-}} / S A_{\mathrm{DIC}}\right) \times\left(1-e^{-\alpha_{2} \mathrm{t}}\right)\right] / \alpha_{2} .
\end{aligned}
$$

The values of $\Delta S A_{\mathrm{CO} 2} / S A_{\mathrm{DIC}}$ and $\Delta S A_{\mathrm{HCO} 3} / S A_{\mathrm{DIC}}$ are set by the difference in $\mathrm{pH}$ between the ${ }^{14} \mathrm{C}$ spike and seawater buffer, with values of 49 and -0.24 , respectively.

\section{Determination of net photosynthesis and Ci fluxes}

The mass spectrometric technique established by Badger et al. (1994) uses the chemical disequilibrium between $\mathrm{CO}_{2}$ and $\mathrm{HCO}_{3}{ }^{-}$during light-dependent $\mathrm{Ci}$ uptake to differentiate between $\mathrm{CO}_{2}$ and $\mathrm{HCO}_{3}^{-}$fluxes across the plasmalemma. It is based on simultaneous measurements of $\mathrm{O}_{2}$ and $\mathrm{CO}_{2}$ during consecutive light and dark intervals. During dark intervals, known amounts of $\mathrm{Ci}$ were added to measure rates as a function of $\mathrm{CO}_{2}$ and $\mathrm{HCO}_{3}{ }^{-}$concentrations. As for all disequilibrium techniques, a lack of eCA activities is required.

Estimates of the $\mathrm{O}_{2}, \mathrm{CO}_{2}$ and $\mathrm{HCO}_{3}{ }^{-}$fluxes were made using equations of Badger et al. (1994). Briefly, rates of $\mathrm{O}_{2}$ consumption in the dark and $\mathrm{O}_{2}$ production in the light were used as direct estimates of respiration and net $\mathrm{Ci}$ fixation, assuming a respiratory quotient of 1.0 and a photosynthetic quotient of 1.1 to convert $\mathrm{O}_{2}$ fluxes into $\mathrm{Ci}$ fluxes. Net $\mathrm{CO}_{2}$ uptake was calculated from the steady-state rate of $\mathrm{CO}_{2}$ depletion at the end of the light period and corrected for the $\mathrm{CO}_{2} / \mathrm{HCO}_{3}^{-}$interconversion in the medium. The $\mathrm{HCO}_{3}{ }^{-}$uptake was derived by a mass balance equation (i.e. the difference of net $\mathrm{Ci}$ fixation and net $\mathrm{CO}_{2}$ uptake). The pseudo-first-order rate constant $k_{2}$ (formation of $\mathrm{CO}_{2}$ from $\mathrm{HCO}_{3}^{-}$) was determined experimentally from the initial slope of $\mathrm{CO}_{2}$ evolution after injection of known amounts of $\mathrm{HCO}_{3}{ }^{-}$into a $\mathrm{CO}_{2}$-free buffered medium. The rate constant $k_{1}$ (formation of $\mathrm{HCO}_{3}^{-}$from $\mathrm{CO}_{2}$ ) was calculated from the product of $k_{2}$ and the ratio of $\mathrm{CO}_{2}$ and $\mathrm{HCO}_{3}{ }^{-}$concentrations. $\mathrm{CO}_{2}$ efflux was estimated from the initial $\mathrm{CO}_{2}$ increase observed directly after the transition from light to dark.

In the present experiments, light/dark intervals during the assay lasted 6 and $7 \mathrm{~min}$, respectively. All measurements were performed in an $\mathrm{f} / 2$ medium, buffered with HEPES (50 $\left.\mathrm{mmol} \mathrm{L}^{-1}, \mathrm{pH} 8.0\right)$ at $15^{\circ} \mathrm{C}$. The incident PFD was $300 \mu \mathrm{mol} \mathrm{m}^{-2} \mathrm{~s}^{-1}$. DBS concentration was $50 \mu \mathrm{mol} \mathrm{L}^{-1}$ in order to ensure the complete inhibition of any eCA activity. Rate constants $k_{1}$ and $k_{2}$ were determined daily in the freshly prepared assay medium, yielding mean values of $1.08( \pm 0.08) \mathrm{min}^{-1}$ and $2.1( \pm 0.2) \times 10^{-2} \mathrm{~min}^{-1}$, respectively. Chl $a$ concentrations in the assays ranged between 0.1 and $0.7 \mu \mathrm{g} \mathrm{mL}^{-1}$.

\section{Isotope fractionation}

Samples for POC were filtered onto pre-combusted QMA filters (Whatman International Ltd, Maidstone, UK) $\left(500{ }^{\circ} \mathrm{C} ; 12 \mathrm{~h}\right)$ and stored at $-25^{\circ} \mathrm{C}$ in pre-combusted Petri dishes $\left(500^{\circ} \mathrm{C} ; 12 \mathrm{~h}\right)$. Prior to the measurement, POC filters were treated with $200 \mu \mathrm{L} \mathrm{HCl}(0.1 \mathrm{~N})$ to remove all $\mathrm{Ci}$ and afterwards dried for $2 \mathrm{~h}$ at $60{ }^{\circ} \mathrm{C}$. POC and related $\delta^{13} \mathrm{C}$ values were measured in duplicate on an EA mass spectrometer (ANCA-SL 20-20, Sercon Ltd, Crewe, UK), with a precision of $\pm 1.5 \mu \mathrm{g} \mathrm{C}$ and $\pm 0.5 \%$, respectively. The isotopic composition is reported relative to the PeeDee belemnite standard (PDB):

$\delta^{13} \mathrm{C}_{\text {sample }}=\left[\frac{\left({ }^{13} \mathrm{C} /{ }^{12} \mathrm{C}\right)_{\text {Sample }}}{\left({ }^{13} \mathrm{C} /{ }^{12} \mathrm{C}\right)_{\mathrm{PDB}}}-1\right] \times 1000$.

Isotope fractionation during POC formation $\left(\varepsilon_{\mathrm{P}}\right)$ was calculated relative to the isotopic composition of $\mathrm{CO}_{2}$ in the medium (Freeman \& Hayes 1992):

$$
\varepsilon_{\mathrm{p}}=\frac{\delta^{13} \mathrm{C}_{\mathrm{CO}_{2}}-\delta^{13} \mathrm{C}_{\mathrm{POC}}}{1+\frac{\delta^{13} \mathrm{C}_{\mathrm{POC}}}{1000}} .
$$

To determine isotopic composition of DIC $\left(\delta^{13} \mathrm{C}_{\mathrm{DIC}}\right), 8 \mathrm{~mL}$ of the culture medium was fixed with $\mathrm{HgCl}$ (final concentration, $140 \mathrm{mg} \mathrm{L}^{-1}$ ). Extractions and measurements were performed in the laboratory of H. J. Spero, University of California, Davis, with a precision of $\pm 0.11 \%$. The isotopic composition of $\mathrm{CO}_{2}\left(\delta^{13} \mathrm{C}_{\mathrm{CO}_{2}}\right)$ was calculated from $\delta^{13} \mathrm{C}_{\mathrm{DIC}}$, making use of a mass balance relation (see Zeebe \& WolfGladrow 2001):

$$
\begin{gathered}
\delta^{13} \mathrm{C}_{\mathrm{HCO}_{3}^{-}}=\frac{\left\{\delta^{13} \mathrm{C}_{\mathrm{DIC}}[\mathrm{DIC}]-\left(\varepsilon_{\mathrm{a}}\left[\mathrm{CO}_{2}\right]+\varepsilon_{\mathrm{b}}\left[\mathrm{CO}_{3}^{2-}\right]\right)\right\}}{\left\{\left(1+\varepsilon_{\mathrm{a}} \times 10^{-3}\right)\left[\mathrm{CO}_{2}\right]+\left[\mathrm{HCO}_{3}^{-}\right]\right.} \\
\left.+\left(1+\varepsilon_{\mathrm{b}} \times 10^{-3}\right)\left[\mathrm{CO}_{3}^{2-}\right]\right\} \\
\delta^{13} \mathrm{C}_{\mathrm{CO}_{2}}=\delta^{13} \mathrm{C}_{\mathrm{HCO}_{3}}\left(1+\varepsilon_{\mathrm{a}} \times 10^{-3}\right)+\varepsilon_{\mathrm{a}}
\end{gathered}
$$


Temperature-dependent fractionation factors between $\mathrm{CO}_{2}$ and $\mathrm{HCO}_{3}^{-}\left(\varepsilon_{\mathrm{a}}\right)$ as well as $\mathrm{HCO}_{3}^{-}$and $\mathrm{CO}_{3}{ }^{2-}\left(\varepsilon_{\mathrm{b}}\right)$ are given by Mook (1986) and Zhang, Quay \& Wilbur (1995), respectively.

\section{RESULTS}

\section{CA activity}

Determination of CA activity using MIMS distinguishes between eCA and iCA activity. Figure 1 shows a representative example for such an assay. The initial increase in the different $\mathrm{CO}_{2}$ traces is due to the label addition. The ${ }^{18} \mathrm{O}$ loss of doubly labelled $\mathrm{HCO}_{3}{ }^{-}$prior and after the addition of cells did not significantly differ, indicating no or only little eCA activity in P. minimum. Growth under higher $\mathrm{pH}$ induced slightly higher activities in P. minimum (Table 1). In $H$. triquetra and $C$. lineatum, eCA activities were close to the detection limit and remained unaffected by the $\mathrm{pH}$ in the incubation. iCA activities were low in all three species and only in P. minimum did it respond to changes in $\mathrm{pH}$. The ${ }^{18} \mathrm{O}$-exchange technique also indicates the presence of light-dependent $\mathrm{Ci}$ transport systems. As shown in Fig. 2, illumination of $H$. triquetra resulted in a faster uptake of ${ }^{18} \mathrm{O}$-labelled ${ }^{13} \mathrm{CO}_{2}(\mathrm{~m} / \mathrm{z}=49$ and 47$)$ and conse-

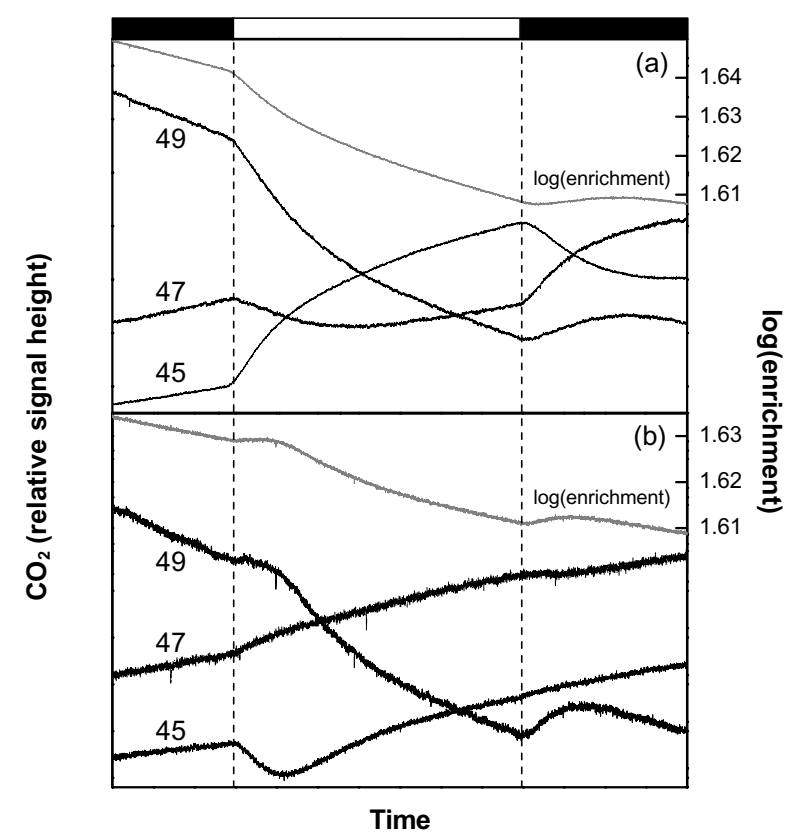

Figure 2. Time course of changes in the relative concentrations of the $\mathrm{CO}_{2}$ isotopes ${ }^{13} \mathrm{C}^{18} \mathrm{O}_{2}(\mathrm{~m} / \mathrm{z}=49),{ }^{13} \mathrm{C}^{16} \mathrm{O}^{18} \mathrm{O}(\mathrm{m} / \mathrm{z}=47),{ }^{13} \mathrm{CO}_{2}$ $(\mathrm{m} / \mathrm{z}=45)$ and the ${ }^{18} \mathrm{O} \log$ (enrichment) by cells of Heterocapsa triquetra (a) and Ceratium lineatum (b). Subsequent to the carbonic anhydrase (CA) measurements, the extracellular CA (eCA) inhibitor dextran-bound sulfonamide (DBS; $50 \mu \mathrm{mol} \mathrm{L}^{-1}$ ) was applied and light was turned on for $4 \mathrm{~min}(300 \mu \mathrm{mol}$ photons $\mathrm{m}^{-2} \mathrm{~s}^{-1}$ ). Black and white bars at the top indicate the dark and light period, respectively. The figure shows representative data from cells acclimated to high $\mathrm{pH}$. The pattern of the ${ }^{18} \mathrm{O}$ exchange in Prorocentrum minimum (not shown) was similar to those for H. triquetra.
Table 1. Chl $a$-specific activities of extracellular carbonic anhydrase (eCA) and intracellular carbonic anhydrase (iCA) activities from cells acclimated to low and high $\mathrm{pH}$. Values represent the mean of three independent measurements $( \pm \mathrm{SD})$

\begin{tabular}{ccc}
\hline \multicolumn{3}{c}{$\mathrm{CA}$ activity } \\
\cline { 2 - 3 } $\mathrm{pH}$ & $\mathrm{eCA}\left[\mathrm{U}(\mathrm{mg} \mathrm{Chl} a)^{-1}\right]$ & $\mathrm{iCA}\left[\Delta(\mathrm{mg} \mathrm{Chl} a)^{-1}\right]$ \\
\hline Prorocentrum & minimum \\
8.0 & $47 \pm 15$ & \\
9.1 & $199 \pm 24$ & $16 \pm 2$ \\
Heterocapsa & triquetra & $24 \pm 1$ \\
8.0 & $13 \pm 3$ & $8 \pm 2$ \\
9.1 & $26 \pm 10$ & $4 \pm 1$ \\
Ceratium lineatum & \\
8.0 & $25 \pm 14$ & $32 \pm 8$ \\
8.5 & $34 \pm 2$ & $29 \pm 1$ \\
\hline
\end{tabular}

CA, carbonic anhydrase.

quent efflux of unlabelled ${ }^{13} \mathrm{CO}_{2}(\mathrm{~m} / \mathrm{z}=45)$, leading to a light-dependent decrease in $\log ($ enrichment). While similar results were obtained for $P$. minimum, illumination induced a different pattern of ${ }^{18} \mathrm{O}$ exchange in C.lineatum. In the latter, light-stimulation in the ${ }^{18} \mathrm{O}$ exchange was less pronounced and observed only in cells acclimated to high $\mathrm{pH}$. Moreover, there was a transient increase in the $\log$ (enrichment) shortly after light was turned on.

\section{${ }^{14} \mathrm{C}$-disequilibrium technique}

The rate of ${ }^{14} \mathrm{C}$ incorporation was monitored over at least $12 \mathrm{~min}$, with emphasis on the first $30 \mathrm{~s}$ and the last $8 \mathrm{~min}$. Monitoring the ${ }^{14} \mathrm{C}$ incorporation well into the equilibrium yielded a high level of precision for determining the contribution of $\mathrm{HCO}_{3}{ }^{-}$. Figure 3 shows an example for the ${ }^{14} \mathrm{C}$ incorporation of P. minimum, acclimated to $\mathrm{pH}$ 8.0. Fitting the data yielded a high contribution of $\mathrm{HCO}_{3}{ }^{-}$relative to net fixation, about $80 \%$ in the given example. When repeated without DBS (control), similar rates of ${ }^{14} \mathrm{C}$ incorporation were obtained, indicating direct uptake of $\mathrm{HCO}_{3}^{-}$ and the absence of significant eCA activity. The latter has already been shown from the ${ }^{18} \mathrm{O}$ exchange. It also indicated that neither the process of concentrating by filtration nor DBS affected the cells negatively. In all three species, the overall proportion of $\mathrm{HCO}_{3}{ }^{-}$makes up about $85 \%$ of the total carbon fixed (Table 2, Fig. 4). In P. minimum, the preference for $\mathrm{HCO}_{3}^{-}$even increases under higher $\mathrm{pH}$, where it contributes about $94 \%$.

\section{Photosynthesis and $\mathrm{Ci}$ fluxes}

The mass spectrometric approach by Badger et al. (1994) is based on simultaneous $\mathrm{O}_{2}$ and $\mathrm{CO}_{2}$ measurements during consecutive light/dark intervals. Figure 5 shows a typical time course of $\mathrm{O}_{2}$ and $\mathrm{CO}_{2}$ concentrations with increasing photosynthetic $\mathrm{O}_{2}$ production and $\mathrm{CO}_{2}$ consumption in the light. After about $3 \mathrm{~min}$, the rate of $\mathrm{O}_{2}$ evolution and $\mathrm{CO}_{2}$ 


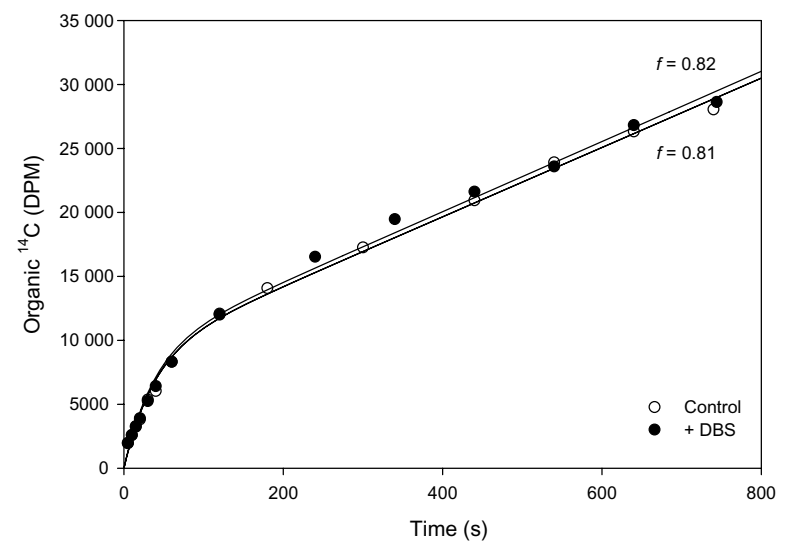

Figure 3. Examples of the results of short-term ${ }^{14} \mathrm{C}$ incubations with cells of Prorocentrum minimum, acclimated to $\mathrm{pH}$ 8.0. Values of $f$ represent the proportion of $\mathrm{HCO}_{3}{ }^{-}$uptake relative to net Cfixation in dextran-bound sulfonamide (DBS)-treated cells $\left(50 \mu \mathrm{mol} \mathrm{L}{ }^{-1}\right)$ and the control. Comparison of DBS-treated cells with the control allows differentiating between direct $\mathrm{HCO}_{3}^{-}$ uptake and CA-mediated $\mathrm{HCO}_{3}^{-}$utilization.

depletion reached a steady state. When the light was turned off, photosynthetic $\mathrm{O}_{2}$ production ceased immediately and was replaced by respiratory $\mathrm{O}_{2}$ consumption. The rapid $\mathrm{CO}_{2}$ increase was caused by both re-equilibration and $\mathrm{CO}_{2}$ efflux. Based on such changes in $\mathrm{O}_{2}$ and $\mathrm{CO}_{2}$ concentration rates of net photosynthesis, $\mathrm{CO}_{2}$ and $\mathrm{HCO}_{3}^{-}$uptake were calculated and expressed as a function of $\mathrm{CO}_{2}$ and/or $\mathrm{HCO}_{3}{ }^{-}$concentration. Representative results of an assay are shown for low- and high-pH-acclimated cells of H. triquetra (Fig. 6). The corresponding kinetic parameters of apparent half-saturating concentrations $\left(K_{1 / 2}\right)$ and maximum rates $\left(V_{\max }\right)$ are summarized in Fig. 7. C. lineatum was affected by the impeller in the cuvette over the duration of the assay and hence was not included in the following comparison.

In terms of the $V_{\max }$ of photosynthesis, P. minimum and H. triquetra were quite similar and the acclimation $\mathrm{pH}$ had

Table 2. Contribution of $\mathrm{HCO}_{3}^{-}$uptake relative to net carbon fixation. Values represent the mean of three generally independent measurements $( \pm \mathrm{SD})$

\begin{tabular}{lll}
\hline & \multicolumn{2}{l}{ Fraction $\mathrm{HCO}_{3}{ }^{-}$} \\
\cline { 2 - 3 } $\mathrm{pH}$ & $\mathrm{DBS}$ & Control \\
\hline \multicolumn{2}{l}{ Prorocentrum minimum } & \\
8.0 & $0.83 \pm 0.022$ & $0.81 \pm 0.024$ \\
9.1 & 0.94 & 0.92 \\
Heterocapsa triquetra & & \\
8.0 & $0.85 \pm 0.002$ & $0.92 \pm 0.016$ \\
9.1 & $0.86 \pm 0.002$ & $0.92 \pm 0.012$ \\
Ceratium lineatum & & \\
8.0 & $0.85 \pm 0.017$ & $0.84 \pm 0.028$ \\
8.5 & $0.85 \pm 0.005$ & $0.85 \pm 0.021$ \\
\hline
\end{tabular}

DBS, dextran-bound sulfonamide.

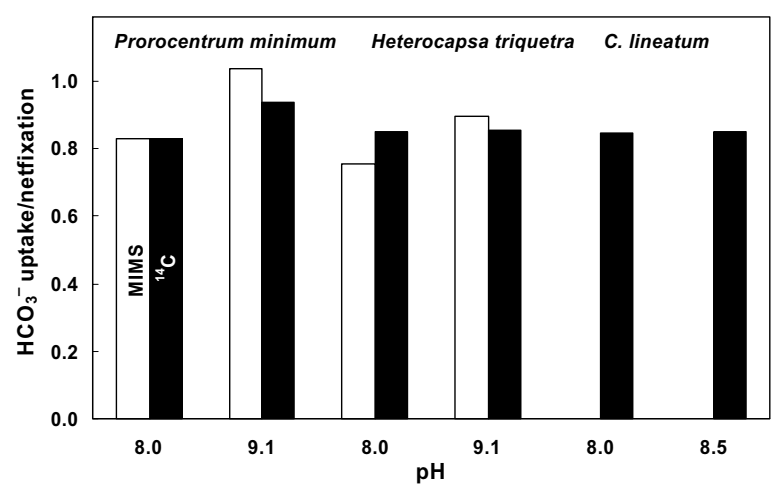

Figure 4. Contribution of $\mathrm{HCO}_{3}^{-}$uptake relative to net photosynthesis determined by inorganic carbon (Ci)-flux measurements (white columns) and ${ }^{14} \mathrm{C}$ disequilibrium technique (black columns) in cells acclimated to different $\mathrm{pH}$. Ratios from membrane inlet mass spectrometry (MIMS) measurements were based on the rates obtained at $\mathrm{Ci}$ concentrations of about $2 \mathrm{mmol} \mathrm{L}^{-1}$. Ci-flux measurements were not obtained for $C$. lineatum because the cells were affected by stirring over the duration of the assay.

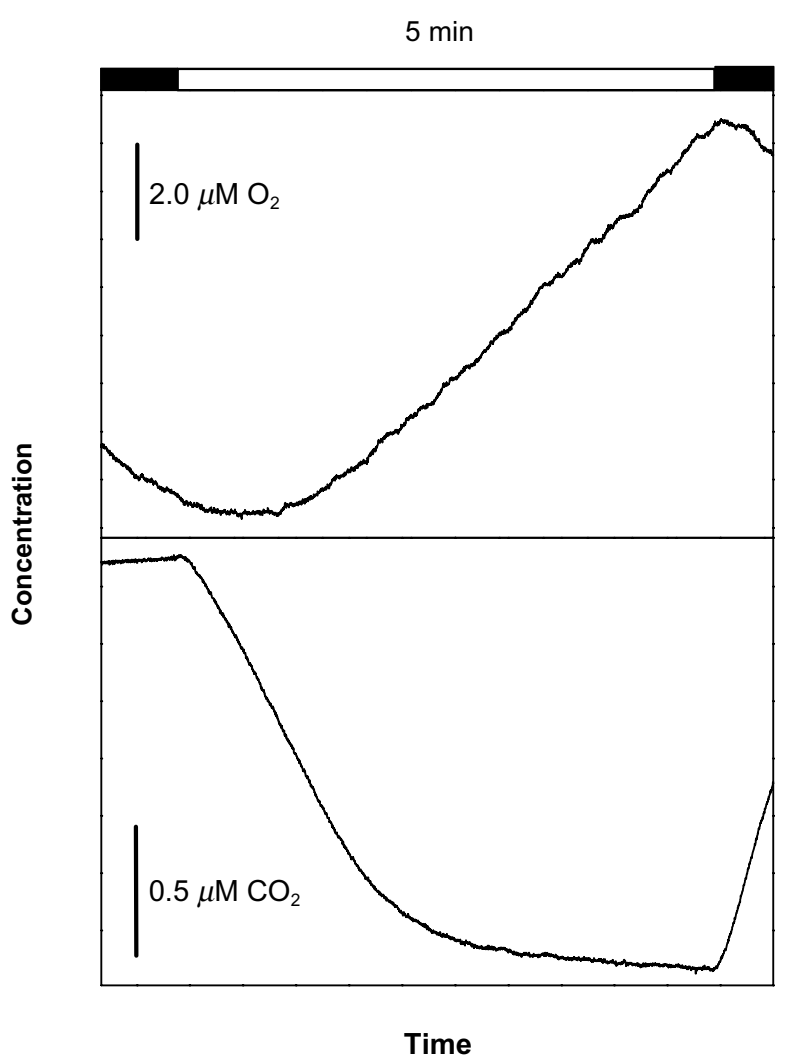

Figure 5. Examples for simultaneous measurements of $\mathrm{O}_{2}$ and $\mathrm{CO}_{2}$ concentrations used to estimate rates of photosynthesis, $\mathrm{CO}_{2}$ uptake and $\mathrm{HCO}_{3}{ }^{-}$uptake. Data shown in this figure were obtained with Heterocapsa triquetra acclimated to $\mathrm{pH}$ 8.0. Black and white bars at the top indicate the dark and light periods, respectively. 


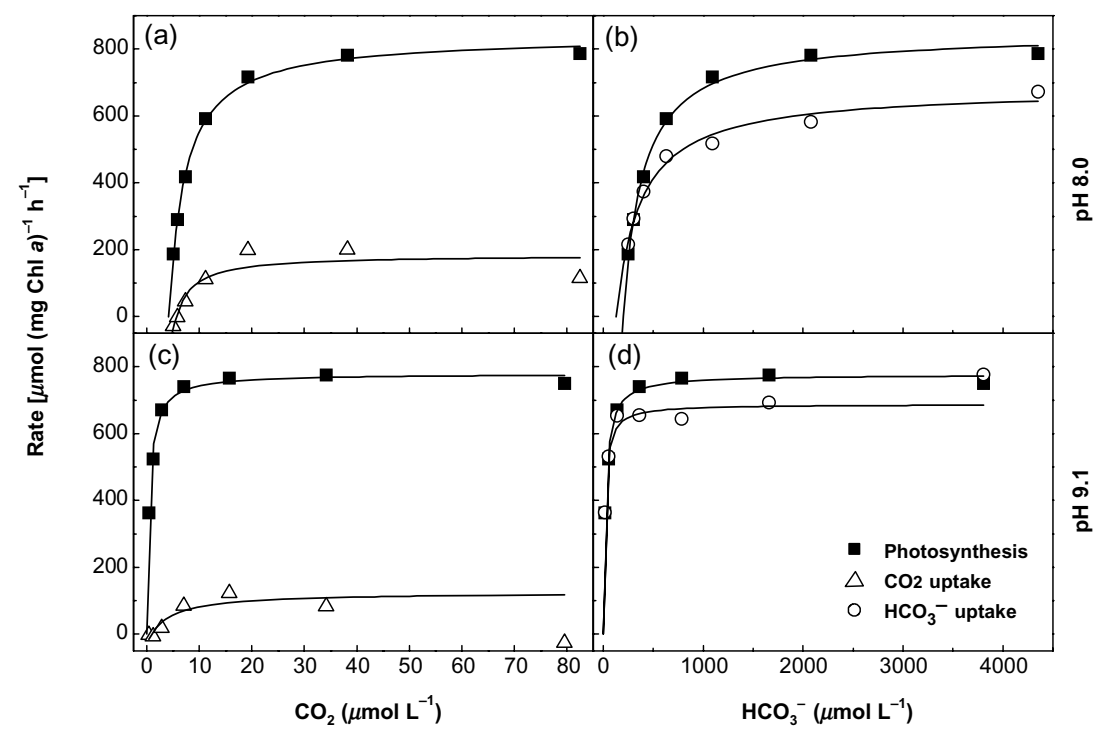

Figure 6. Chl $a$-specific rates of net photosynthesis (squares), net $\mathrm{CO}_{2}$ uptake (triangles) and $\mathrm{HCO}_{3}{ }^{-}$uptake (circles) as a function of $\mathrm{CO}_{2}$ or $\mathrm{HCO}_{3}^{-}$concentration in the assay medium for Heterocapsa triquetra. Prior to the measurements, cultures were acclimated to $\mathrm{pH} 8.0$ (a, b) and $\mathrm{pH} 9.1$ (c, d). Curves were obtained from a MichaelisMenten fit. no large effect (Fig. 7). As indicated by their $K_{1 / 2}$ values, affinities for $\mathrm{Ci}$ differed significantly between species and acclimations. P.minimum showed lower apparent $K_{1 / 2}$ $\left(\mathrm{HCO}_{3}{ }^{-}\right)$for photosynthesis than H. triquetra when acclimated to $\mathrm{pH}$ 8.0. Acclimation to high $\mathrm{pH}$ caused these values to decrease strongly, and thus, the differences between the two species diminished. For both species, $K_{1 / 2}\left(\mathrm{CO}_{2}\right)$ for photosynthesis were much lower than could be expected from diffusive $\mathrm{CO}_{2}$ uptake alone. With values between 0.5

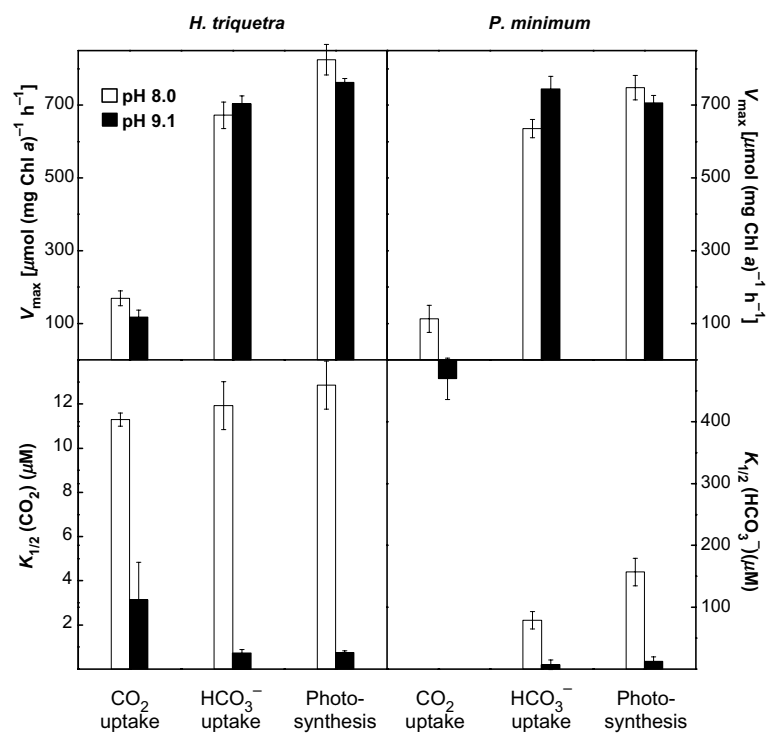

Figure 7. Maximum rates $\left(V_{\max }\right)$ and half-saturation concentrations $\left(K_{1 / 2}\right)$ of photosynthesis, net $\mathrm{CO}_{2}$ uptake and $\mathrm{HCO}_{3}{ }^{-}$uptake for Heterocapsa triquetra and Prorocentrum minimum acclimated to $\mathrm{pH} 8.0$ (white columns) and $\mathrm{pH} 9.1$ (black columns). With the exception of the $\mathrm{CO}_{2}$ uptake in H. triquetra, $K_{1 / 2}$ values are reported as $\mu \mathrm{mol} \mathrm{HCO}_{3}^{-} \mathrm{L}^{-1}$. Kinetic parameters were calculated from a Michaelis-Menten fit to the combined data of several independent measurements. Error bars denote \pm SD $(n=3)$. and $8.1 \mu \mathrm{mol} \mathrm{L}^{-1} \mathrm{CO}_{2}$, this is at least one order of magnitude lower than $K_{\mathrm{M}}$ values reported for Rubisco (Badger et al. 1998).

Rates of $\mathrm{CO}_{2}$ uptake were very low in both species, especially when compared with rates of carbon fixation (Fig. 7). In fact, net $\mathrm{CO}_{2}$ uptake was even negative for P. minimum at times, which made it impossible to calculate $K_{1 / 2}$ values. In H. triquetra, $K_{1 / 2}$ values for $\mathrm{CO}_{2}$ uptake were 11.3 and $3.1 \mu \mathrm{mol} \mathrm{L}-1 \mathrm{CO}_{2}$ when grown at $\mathrm{pH} 8.0$ and 9.1, respectively. Because $\mathrm{CO}_{2}$ uptake could not support the observed rates of photosynthesis, most of the $\mathrm{Ci}$ was taken up as $\mathrm{HCO}_{3}{ }^{-}$. The contribution of $\mathrm{HCO}_{3}{ }^{-}$uptake relative to total carbon fixation was more than $80 \%$, even under low $\mathrm{pH}$ (Figs 4 \& 7). $K_{1 / 2}$ values for $\mathrm{HCO}_{3}{ }^{-}$uptake were generally lower for P. minimum than for H. triquetra. For both species, $K_{1 / 2}$ values strongly decreased with increasing $\mathrm{pH}$; from 79 to $7 \mu \mathrm{mol} \mathrm{L}{ }^{-1} \mathrm{HCO}_{3}^{-}$for P. minimum and from 426 to $26 \mu \mathrm{mol} \mathrm{L}^{-1} \mathrm{HCO}_{3}^{-}$for $H$. triquetra.

The leakage of the cells (i.e. the proportion of $\mathrm{Ci}$ efflux compared to gross $\mathrm{Ci}$ uptake), was estimated from the $\mathrm{CO}_{2}$ efflux observed directly upon darkening (Badger et al. 1994). As shown in Fig. 8, cellular leakage differed between species, being highest in C.lineatum and lowest in $H$. triquetra. In cells acclimated to low $\mathrm{pH}$, leakage was always highest under low ambient $\mathrm{CO}_{2}$ and levelled off towards higher $\mathrm{CO}_{2}$ concentrations in the assay. Moreover, leakage seemed to decrease with increasing $\mathrm{pH}$ in the incubation.

\section{Isotope fractionation}

Samples from each species and $\mathrm{pH}$ incubation were taken to determine the isotopic composition of organic carbon $\left(\delta^{13} \mathrm{C}_{\mathrm{POC}}\right)$ and $\mathrm{Ci}\left(\delta^{13} \mathrm{C}_{\mathrm{DIC}}\right)$, allowing us to calculate ${ }^{13} \mathrm{C}$ fractionation of the cells. Fractionation values $\left(\varepsilon_{\mathrm{P}}\right)$ obtained in this study were generally low, with highest values of $14.4 \%$ o in C.lineatum, $9.9 \%$ in $H$. triquetra and $8.6 \%$ in P. minimum (Fig.9). In all species, a higher $\mathrm{pH}$ in the 


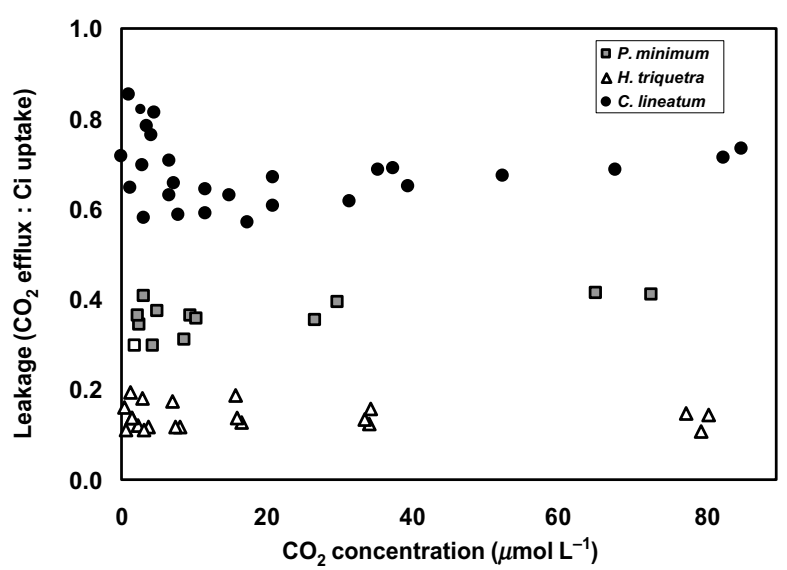

Figure 8. Leakage $\left[\mathrm{CO}_{2}\right.$ efflux : gross inorganic carbon $(\mathrm{Ci})$ uptake] as a function of the $\mathrm{CO}_{2}$ concentration in the assay, obtained from cells of Prorocentrum minimum, Heterocapsa triquetra and Ceratium lineatum acclimated to high $\mathrm{pH}$.

acclimation caused $\varepsilon_{\mathrm{P}}$ to decrease by 5 to $10 \%$, even yielding negative $\varepsilon_{\mathrm{P}}$ values $\left(-1.1 \%\right.$ ) in P. minimum. Such low $\varepsilon_{\mathrm{P}}$ values were consistent with predominant $\mathrm{HCO}_{3}{ }^{-}$use. Observed $\varepsilon_{\mathrm{P}}$ differences between low and high $\mathrm{pH}$, moreover, reflected changes in leakage.

\section{DISCUSSION}

Recent studies suggest that photosynthesis and growth in marine dinoflagellates may be $\mathrm{CO}_{2}$ limited in the natural environment even at air-equilibrated levels found in open waters (Colman et al. 2002; Dason et al. 2004). In productive coastal waters, $\mathrm{Ci}$ limitation may be more severe during algal blooms when the $\mathrm{pH}$ is high. In this study, several aspects of $\mathrm{Ci}$ acquisition in three bloom-forming dinoflagellates were investigated by applying different independent methods, such as MIMS techniques for CA activity and $\mathrm{Ci}$ fluxes, as well as the ${ }^{14} \mathrm{C}$-disequilibrium technique. The central aim was to describe modes of carbon acquisition under conditions that match the natural environment as much as possible.

\section{CA activity}

eCA, which accelerates the conversion of $\mathrm{HCO}_{3}{ }^{-}$to $\mathrm{CO}_{2}$ at the cell surface, was found to increase in response to decreasing $\mathrm{CO}_{2}$ concentrations or increasing $\mathrm{pH}$ in many microalgae (Sültemeyer 1998 and references therein). It is a common notion that eCA increases the $\mathrm{CO}_{2}$ concentration at the plasma membrane and herewith favours $\mathrm{CO}_{2}$ uptake, also referred to as indirect $\mathrm{HCO}_{3}{ }^{-}$utilization. Other microalgal species were found not to induce eCA even when grown under severe carbon limitation (e.g. Burkhardt et al. 2001; Rost et al. 2003). In the present study, eCA activities were very low in all treatments (Table 1) and only in P. minimum did DBS addition cause these activities to considerably decrease (data not shown). The absence of significant eCA activities has also been demonstrated by the ${ }^{14} \mathrm{C}$-disequilibrium technique, which yielded similar rates of ${ }^{14} \mathrm{C}$ incorporation in DBS-treated, as well as in nontreated, cells. Although some eCA activity could be detected by monitoring ${ }^{18} \mathrm{O}$ loss from labelled $\mathrm{HCO}_{3}{ }^{-}$, these activities are negligible when compared to other species. P. minimum showed the highest values and only in this species did $\mathrm{pH}$ have a noteworthy effect on eCA activity. When grown at pH 8.0 and 9.1, eCA activities were 50 and $200 \mathrm{U}(\mathrm{mg} \mathrm{Chl} a)^{-1}$, respectively. In other words, the rate of interconversion between $\mathrm{HCO}_{3}^{-}$and $\mathrm{CO}_{2}$ increased 0.5 - to 2-fold relative to the uncatalysed rate per milligram $\mathrm{Chl} a$. Activities observed in other taxa, such as the diatom Skeletonema costatum or the prymnesiophyte Phaeocystis globosa, were at least one order of magnitude higher under similar growth conditions (Rost et al.2003). Based on these findings, it seems that eCA is playing only a minor role, if any, in the three investigated dinoflagellates.

The low eCA activities observed in the present study are consistent with results of other studies on dinoflagellates. Instead of monitoring ${ }^{18} \mathrm{O}$ loss by mass spectrometry, most other studies on dinoflagellates used a potentiometric approach to assess CA activities (Wilbur \& Anderson 1948). Using this approach Dason et al. (2004) measured eCA activities in Amphidinium carterae and Heterocapsa oceanica, yielding Wilbur-Anderson units of $5.05 \pm 3.29$ and $4.34 \pm 1.29(\mathrm{mg} \mathrm{Chl} a)^{-1}$, respectively. These eCA activities correspond to a four- to fivefold enhancement in the conversion of $\mathrm{HCO}_{3}^{-}$to $\mathrm{CO}_{2}$ relative to the uncatalysed rate per milligram $\mathrm{Chl} a$. These values are within the same magnitude as our results. Nimer, Iglesias-Rodriguez \& Merrett (1997) investigated various species, including five species of dinoflagellates, finding relatively low eCA activities in all species and acclimations. In the fresh water dinoflagellates Peridinium gatunense, eCA activities were low at the onset of the bloom, but increased up to $570 \mathrm{U}(\mathrm{mg} \mathrm{Chl} a)^{-1}$ towards the end of the bloom (Berman-Frank et al. 1995). It should be noted here that the mass spectrometric procedure allows the determination of CA activity from living cells under conditions similar to those during growth. As pointed out by Dason et al. (2004), the potentiometric assay may yield erroneous eCA activities owing to low assay

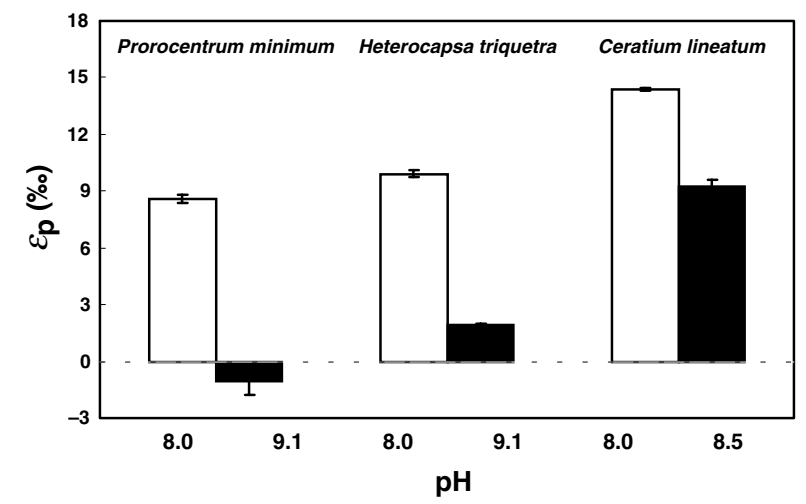

Figure 9. Isotope fractionation $\left(\varepsilon_{\mathrm{p}}\right)$ as a function of $\mathrm{pH}$ in the acclimation, calculated from the ${ }^{13} \mathrm{C}_{\mathrm{CO} 2}$ and ${ }^{13} \mathrm{C}_{\mathrm{POC}}$ in their respective acclimation. Error bars denote $\pm \mathrm{SD}(n=3)$. 
temperatures and the use of a dilute buffer, which can cause an osmotic shock and, hence, the release of some internal CA.

The physiological role of iCA, which can be located in the chloroplast, the mitochondria and in the cytosol, is still not fully understood (Sültemeyer 1998). The importance of iCA in $\mathrm{Ci}$ acquisition has, however, been demonstrated in various studies by the effect of the membrane-permeable CA inhibitor, ethoxyzolamide, on photosynthesis (Badger et al. 1998 and references therein). According to Palmqvist et al. (1994), when interpreting iCA activities, one has to bear in mind that $\Delta$ values are in vivo estimates and are dependent not only on the speed of intracellular ${ }^{18} \mathrm{O}$-depletion but also on the diffusive influx of doubly labelled $\mathrm{CO}_{2}$, and thus, on the diffusive properties of algal membranes and cell shape. Consequently, $\Delta$ values are arbitrary units which allow direct comparison of different treatments, but not necessarily between species. All three species in this investigation possess internal CA activity. Results of Burkhardt et al. (2001) indicate a gradual increase in iCA activity of two marine diatoms in response to increasing $\mathrm{pH}$ or decreasing $\mathrm{CO}_{2}$ supply. Our data does confirm such $\mathrm{pH}$ dependence in iCA activity only for P. minimum.

Using the ${ }^{18} \mathrm{O}$-exchange technique, we also examined the presence of light-dependent $\mathrm{Ci}$ transport systems. In the case of active $\mathrm{Ci}$ uptake, a decline in $\log$ (enrichment) during illumination would be expected, which is caused by an enhanced influx of ${ }^{18} \mathrm{O}$-labelled $\mathrm{CO}_{2}$ and $\mathrm{HCO}_{3}{ }^{-}$into the cells to the active site of iCA, increased ${ }^{18} \mathrm{O}$ loss and subsequent efflux of ${ }^{18} \mathrm{O}$-unlabelled $\mathrm{CO}_{2}$ (Badger \& Price 1989; Palmqvist et al. 1994). Such a net $\mathrm{CO}_{2}$ efflux from photosynthesizing cells result from the accumulation of $\mathrm{CO}_{2}$ inside the cell relative to ambient $\mathrm{CO}_{2}$ concentration. As shown in Fig. 2, illumination of $H$. triquetra resulted in an uptake of ${ }^{13} \mathrm{C}^{18} \mathrm{O}_{2}(\mathrm{~m} / \mathrm{z}=49)$ and an efflux of ${ }^{13} \mathrm{C}^{16} \mathrm{O}_{2}(\mathrm{~m} /$ $\mathrm{z}=45$ ), that is, a light-dependent decrease in $\log$ (enrichment). Similar ${ }^{18} \mathrm{O}$ exchange was also observed for P. minimum (data not shown). These responses to illumination have also been observed in the symbiotic dinoflagellates Symbiodinium (Badger et al. 1998; Leggat et al. 1999), various other microalgae (Palmqvist et al. 1994, 1995; Badger et al. 1998) and cyanobacteria (Badger \& Price 1989), all of which operate a CCM. In C. lineatum, lightstimulation in ${ }^{18} \mathrm{O}$ exchange was less pronounced, with a transient increase in the $\log$ (enrichment) shortly after light was turned on. The greater lag phase could be explained by a slower induction of the $\mathrm{Ci}$ uptake in this species, which is leading to a situation right after illumination in which external $\mathrm{Ci}$ species are in equilibrium with the internal compartment. When light activates photosynthesis under these conditions, there is a competition between Rubisco and $\mathrm{Ci}$ hydration processes for $\mathrm{CO}_{2}$, causing the enrichment to rise rather than to fall (see Badger et al. 1998).

\section{Photosynthetic $\mathrm{O}_{2}$ evolution}

In comparison to other taxa, dinoflagellates are known to be the most sensitive to turbulence (Thomas \& Gibson
1990). We therefore tried to minimize the shear forces on the cells during the measurements by optimizing the stirring mechanism in the cuvette and working with relatively low stirring speed. Time-course experiments confirmed that rates for photosynthesis of P. minimum and H. triquetra remained unaltered over the duration of the assay. In fact, $V_{\max }$ of photosynthesis in these species (Fig. 7) were relatively high when compared to previous studies on dinoflagellates (e.g. Goiran et al. 1996; Leggat et al. 1999; Nimer et al. 1999; Dason et al. 2004). Time-course experiments with $C$. lineatum, however, showed that rates of photosynthesis decreased by as much as $40 \%$ over the duration of the assay. Consequently, C. lineatum is not included in the following comparison on the kinetics of photosynthesis and $\mathrm{Ci}$ uptake.

Monitoring photosynthetic $\mathrm{O}_{2}$ evolution as a function of $\mathrm{CO}_{2}$ concentration in the assays provides important information on the carbon acquisition of microalgae. Lower apparent $K_{1 / 2}\left(\mathrm{CO}_{2}\right)$ than $K_{\mathrm{M}}\left(\mathrm{CO}_{2}\right)$ of Rubisco suggests the operation of a CCM (Badger et al. 1998). Treatmentinduced changes in affinities bear further more information on the efficiency and capability to regulate the CCM. In our experiments, $K_{1 / 2}\left(\mathrm{CO}_{2}\right)$ for photosynthesis were very low when compared to values known for Rubisco, especially in comparison to type II Rubisco (Whitney \& Andrews 1998). P. minimum and H. triquetra both responded to high $\mathrm{pH}$ by increasing the apparent affinities for Ci. In P. minimum, $K_{1 / 2}\left(\mathrm{CO}_{2}\right)$ of photosynthesis decreased from 3.2 to $1.6 \mu \mathrm{mol}$ $\mathrm{L}^{-1}$ with increasing $\mathrm{pH}$ in the acclimation. In H. triquetra, acclimation to high $\mathrm{pH}$ had a stronger effect on the upregulation of the CCM, causing $K_{1 / 2}\left(\mathrm{CO}_{2}\right)$ to drop from 8.1 to $0.5 \mu \mathrm{mol} \mathrm{L}-1$ when grown at $\mathrm{pH} 8.0$ and 9.1 , respectively. These affinities are comparable with previous observations, for instance $K_{1 / 2}\left(\mathrm{CO}_{2}\right)$ of Symbiodinium sp. being smaller than $3 \mu \mathrm{mol} \mathrm{L}^{-1}$ (Caperon \& Smith 1978). In P. gatunense, similar changes in affinities as a function of $\mathrm{pH}$ were observed, as $K_{1 / 2}\left(\mathrm{CO}_{2}\right)$ for photosynthesis decreased from 4 to $0.1 \mu \mathrm{mol} \mathrm{L}{ }^{-1}$ when grown at $\mathrm{pH} 8.3$ and 9.1, respectively (Berman-Frank et al. 1998).

Such low $K_{1 / 2}\left(\mathrm{CO}_{2}\right)$ of photosynthesis relative to the $K_{\mathrm{M}}\left(\mathrm{CO}_{2}\right)$ of Rubisco suggest high accumulation of $\mathrm{CO}_{2}$ at the site of Rubisco. The $K_{\mathrm{M}}: K_{1 / 2}$ ratio approximates for such an internal $\mathrm{CO}_{2}$ enrichment relative to ambient $\mathrm{CO}_{2}$ concentrations. Due to the unstable nature of dinoflagellates Rubisco absolute kinetic parameters are not yet known. However, some estimates can be made based on the $S_{\text {rel }}$ values obtained for A. carterae (Whitney \& Andrews 1998). Assuming a $K_{\mathrm{M}}$ of $60 \mu \mathrm{mol} \mathrm{L}{ }^{-1}$ (Leggat et al. 1999), the $K_{\mathrm{M}}: K_{1 / 2}$ ratio indicate a $\mathrm{CO}_{2}$ accumulation of about 19 - to 37 -fold in P. minimum. In $H$. triquetra, $K_{1 / 2}\left(\mathrm{CO}_{2}\right)$ values could theoretically be achieved by a $\mathrm{CO}_{2}$ accumulation of about 7 - to 120 -fold.

Intracellular accumulation of $\mathrm{Ci}$ has been directly measured in dinoflagellates by silicon-oil centrifugation. Leggat et al. (1999) observed similar $\mathrm{Ci}$ accumulation of about 5- to 25-fold in Symbiodinium sp. and A. caterae, while Berman-Frank et al. (1998) calculated 5- to 70-fold Ci accumulation for P.gatunense. In Prorocentrum micans, 
a 10-fold $\mathrm{Ci}$ accumulation relative to external concentration was measured (Nimer et al. 1999). These Ci accumulation factors in dinoflagellates obtained by silicon-oil centrifugation seem low in comparison to $K_{\mathrm{M}}: K_{1 / 2}$ ratios, which indicate rather high $\mathrm{CO}_{2}$ accumulation at Rubisco. This finding may point to a localized $\mathrm{Ci}$ accumulation in the chloroplast, such as the stroma rather than of the whole cell. More accurate estimates of internal $\mathrm{CO}_{2}$ accumulation will require full kinetic characterization of dinoflagellate Rubisco.

\section{Carbon source and uptake kinetics}

Although $\mathrm{CO}_{2}$ dependence in $\mathrm{O}_{2}$ evolution reveals information about the efficiency and regulation of the CCM, it can not provide any details about the underlying mechanisms such as the transport systems. Various methods have been employed to distinguish between $\mathrm{CO}_{2}$ and $\mathrm{HCO}_{3}^{-}$ uptake in microalgae. In this study, estimates of net $\mathrm{CO}_{2}$ and $\mathrm{HCO}_{3}^{-}$uptake rates were obtained by a method of Badger et al. (1994), which has the advantage of having the capability to quantify Ci fluxes during steady-state photosynthesis. Rates of $\mathrm{CO}_{2}$ uptake were very low in both species, representing less than $20 \%$ relative to carbon fixation in all acclimations (Fig. 7). Owing to the low contribution of $\mathrm{CO}_{2}$ to the overall carbon fixation, $K_{1 / 2}$ values could not be calculated for P.minimum. In H.triquetra apparent affinities for $\mathrm{CO}_{2}$ increased with $\mathrm{pH}$. Both species caused the $\mathrm{CO}_{2}$ concentration to decrease below disequilibrium concentrations in the light, which has been confirmed by the addition of bovine $\mathrm{CA}$ (data not shown). Because $\mathrm{CO}_{2}$ uptake could not support the observed rates of photosynthesis, most of the $\mathrm{Ci}$ was taken up as $\mathrm{HCO}_{3}^{-}$. In both species, $\mathrm{HCO}_{3}{ }^{-}$uptake contributed more than $80 \%$ of the total carbon fixation. Apparent affinities for $\mathrm{HCO}_{3}^{-}$were generally higher for P. minimum than for H.triquetra. Acclimation to high $\mathrm{pH}$ caused a strong increase in apparent affinities for $\mathrm{HCO}_{3}^{-}$, indicated by the generally lower $K_{1 / 2}$ values.

In a second approach, we applied the ${ }^{14} \mathrm{C}$-disequilibrium technique to gain independent information on the carbon source taken by the cells (Espie \& Colman 1986; Elzenga et al.2000). This technique has been applied in field studies because the assay can be performed with the lowest cell concentrations, requires no calibration and takes a relatively short time (Tortell \& Morel 2002; Cassar et al. 2004). Moreover, stirring in the cuvette can be slow, and hence, allow measurements of very sensitive species like C. lineatum. It should be noted, however, that neither rates nor affinities for $\mathrm{CO}_{2}$ or $\mathrm{HCO}_{3}{ }^{-}$uptake can be calculated by this approach. The proportion of $\mathrm{HCO}_{3}{ }^{-}$relative to carbon fixation was high in all three species, making up between about 83 and $95 \%$ (Table 2). Comparing the relative contribution of $\mathrm{HCO}_{3}{ }^{-}$obtained by this approach with those obtained by Ci-flux measurements (MIMS), we get similar results (Fig. 4). This assures $\mathrm{HCO}_{3}{ }^{-}$as the dominant carbon source taken up.

Our findings contradict with a recent study on free-living dinoflagellates, which found no evidence for $\mathrm{HCO}_{3}{ }^{-}$use in
A. carterae and H. oceanica (Dason et al. 2004). Their conclusion is mainly based on rather low rates of photosynthetic $\mathrm{O}_{2}$ evolution in comparison to the spontaneous rate of $\mathrm{CO}_{2}$ formation. We argue that while rates of photosynthesis higher than the spontaneous $\mathrm{CO}_{2}$ delivery from the $\mathrm{HCO}_{3}{ }^{-}$pool may indicate $\mathrm{HCO}_{3}{ }^{-}$use, the reverse conclusion is not valid. In addition, rates of photosynthesis in Dason et al. (2004) could be suppressed by photoinhibition, as the cells were acclimated to $75 \mu \mathrm{mol}$ photons $\mathrm{m}^{-2} \mathrm{~s}^{-1}$, while rates of photosynthesis were assessed at $1000 \mu \mathrm{mol}$ photons $\mathrm{m}^{-2} \mathrm{~s}^{-1}$. A preference for $\mathrm{CO}_{2}$ in dinoflagellates was also deduced from the stimulation of photosynthesis upon CA addition (Dason et al. 2004) or the inhibition of photosynthesis upon DBS addition (Nimer et al. 1999). None of these effects were observed in our study. CA addition abolished chemical disequilibrium in the light and hereby increased $\mathrm{CO}_{2}$ concentrations relative to $\mathrm{Ci}$, but it had no effect on the net photosynthesis (data not shown). Addition of DBS did not alter rates of photosynthesis either (see, for instance, ${ }^{14} \mathrm{C}$-incorporation rates with and without DBS in Fig. 3).

\section{Fractionation and leakage}

Photosynthetic carbon fixation discriminates against the heavier ${ }^{13} \mathrm{CO}_{2}$ causing the isotopic composition of organic material $\left(\delta^{13} \mathrm{C}_{\mathrm{POC}}\right)$ to be depleted in ${ }^{13} \mathrm{C}$, compared with the Ci source. Most of this fractionation $\left(\varepsilon_{\rho}\right)$ is driven by the discrimination of ${ }^{13} \mathrm{C}$ by Rubisco $\left(\varepsilon_{\mathrm{f}}\right)$, here assumed to be about 30\%o (Raven \& Johnston 1991). While $\varepsilon_{\mathrm{f}}$ sets the uppermost values for $\varepsilon_{\mathrm{P}}$, variations are principally determined by $\mathrm{Ci}$ leakage $(L)$ and the carbon source taken up (Sharkey \& Berry 1985):

$\varepsilon_{\mathrm{P}}=a \times \varepsilon_{\mathrm{s}}+L \times \varepsilon_{\mathrm{f}}$.

$\varepsilon_{\mathrm{S}}$ represents the equilibrium discrimination between the carbon sources $\mathrm{CO}_{2}$ and $\mathrm{HCO}_{3}^{-}$(approx $-10 \%$ ) and $a$ is the fractional contribution of $\mathrm{HCO}_{3}^{-}$to total $\mathrm{Ci}$ uptake. Because $\mathrm{HCO}_{3}^{-}$is enriched in ${ }^{13} \mathrm{C}$ relative to $\mathrm{CO}_{2}$, an increasing proportion of $\mathrm{HCO}_{3}^{-}$uptake decreases the apparent isotope fractionation $\varepsilon_{\mathrm{p}}$, which is defined relative to $\mathrm{CO}_{2}$ as the carbon source. If there is no change in the $\mathrm{Ci}$ source, $\varepsilon_{\mathrm{p}}$ decreases with decreasing leakage. Based on these simple considerations, fractionation values may provide information on the mode of carbon acquisition and vice versa.

In terms of information on the carbon source, only extreme $\varepsilon_{\mathrm{p}}$ values allow precluding one carbon source. If $\varepsilon_{\mathrm{p}}$ is lower than $0 \%, \mathrm{CO}_{2}$ can be excluded as the only carbon source and $\varepsilon_{\mathrm{p}}$ values higher than $20 \%$ rule out $\mathrm{HCO}_{3}{ }^{-}$as the only carbon source. $\varepsilon_{\mathrm{P}}$ values in our experiments (Fig. 9) are within this range, which is consistent with predominant $\mathrm{HCO}_{3}{ }^{-}$use. The negative $\varepsilon_{\mathrm{P}}$ values of $-1.1 \%$ in $P$. minimum even precluded $\mathrm{CO}_{2}$ as the only carbon source. BermanFrank et al. (1998) observed high $\delta^{13} \mathrm{C}_{\mathrm{POC}}$ values ( -23 to $-16 \%$ ) in $P$. gatunense, indicating low fractionation values in this species. Variations in fractionation are particular sensitive to changes in leakage (see Eqn 11). In all species 
investigated, high $\mathrm{pH}$ caused $\varepsilon_{\mathrm{P}}$ to drop by $5-10 \%$. As $\mathrm{HCO}_{3}{ }^{-}$is the predominant carbon source under both $\mathrm{pH}$ acclimations (Fig. 4), changes in $\varepsilon_{\mathrm{P}}$ mostly reflect changes in leakage. Consequently, cells seem to greatly reduce their leakage with increasing $\mathrm{pH}$ or decreasing $\mathrm{CO}_{2}$ concentrations. Moreover, based on the large differences in $\varepsilon_{\mathrm{P}}$, leakage appears to be highest in C. lineatum and lowest in P. minimum.

The efficiency of a CCM does not only depend on the kinetics of the carbon uptake systems but also on the loss of $\mathrm{Ci}$ via efflux. High leakage will increase the energetic costs of a CCM and/or decrease its capability to reach carbon saturation (Raven \& Lucas 1985; Spalding \& Portis 1985). In this respect, it is necessary to minimize the relative loss of $\mathrm{Ci}$ by leakage at low ambient $\mathrm{CO}_{2}$ concentration, hereby increasing their overall CCM efficiency. At the same time, however, there is a greater potential for leakage owing to lower ambient $\mathrm{CO}_{2}$ concentrations and higher $K_{\mathrm{M}}: K_{1 / 2}$ ratio, both causing the outward $\mathrm{CO}_{2}$ gradient to be higher. According to Fick's law, the $\mathrm{CO}_{2}$ flux via a membrane is a function of the $\mathrm{CO}_{2}$ concentration gradient and a permeability coefficient. Higher apparent resistance for $\mathrm{CO}_{2}$ diffusion could be caused by changes in membrane properties, but it may also point to a more localized $\mathrm{Ci}$ accumulation in the chloroplast and to changes of the pyrenoid. Species-specific differences in leakage, as deduced from $\varepsilon_{\mathrm{P}}$ values, may reflect lower CCM efficiency in C. lineatum relative to $P$. minimum and $H$. triquetra.

We also estimated leakage in the Ci-flux assays from the $\mathrm{CO}_{2}$ efflux observed directly upon darkening (Badger et al. 1994). The calculation is based on the assumption that leakage occurs mainly by diffusion of $\mathrm{CO}_{2}$ and that the rate of diffusive $\mathrm{CO}_{2}$ efflux in the light is well represented by the rate of $\mathrm{CO}_{2}$ efflux during the first seconds of the subsequent dark phase. This approach may underestimate the real $\mathrm{Ci}$ efflux due to re-fixation of $\mathrm{CO}_{2}$ by internal ribulose-bisphosphate in the dark and a slow response time of the MIMS. Moreover, microalgae release relatively small amounts of $\mathrm{CO}_{2}$ in the dark, as they build up only small internal $\mathrm{Ci}$ pools. Considering these uncertainties, absolute values for leakage should be treated with caution. In the comparison we also included $C$. lineatum because only relative numbers were used here. Cellular leakage differed between species (Fig. 8), being highest in C.lineatum and lowest in $H$. triquetra. These findings are consistent with the speciesspecific differences in $\varepsilon_{\mathrm{P}}$.

\section{CONCLUSIONS}

Much of the effort in investigating carbon acquisition in marine phytoplankton has focused on diatoms and coccolithophores. Limited studies have focused on the experimentally less tractable dinoflagellates (Giordano et al. 2005). These few studies suggest that photosynthesis and growth in dinoflagellates may be $\mathrm{CO}_{2}$ limited in the marine environment and that they probably are restricted to $\mathrm{CO}_{2}$ enriched micro-environments (Colman et al. 2002; Dason et al. 2004). The data of our investigation do not support this view. All three dinoflagellates predominantly use $\mathrm{HCO}_{3}{ }^{-}$as their $\mathrm{Ci}$ source. For the two species that could be investigated using Ci-flux measurements, high affinities for $\mathrm{Ci}$ were found. This suggests that these dinoflagellates are not limited by $\mathrm{Ci}$ in open waters, which are characterized by only small changes in DIC and rather moderate changes in $\mathrm{pH}$. In view of the ongoing increase in atmospheric $\mathrm{pCO}_{2}$, concomitant changes in the carbonate chemistry will most likely not directly affect the rate of carbon fixation in these species.

However, could $\mathrm{Ci}$ be limiting for dinoflagellates in more productive coastal waters? In these environments, $\mathrm{pH}$ may become elevated and reach values above 9, and in some cases even up to 9.75, during red tides (Hansen 2002). Under such conditions, DIC will not only be significantly reduced, but a large part of the $\mathrm{Ci}$ pool will be in the form of $\mathrm{CO}_{3}{ }^{2-}$, which may be not directly accessible for the algae. It is known that the sensitivity of marine dinoflagellates to high $\mathrm{pH}$ differs among species. In $\mathrm{pH}$-drift experiments, some dinoflagellates can grow until $\mathrm{pH}$ reaches 10.3 , while the growth of others stops already at $\mathrm{pH} 8.3-8.4$ (e.g. Hansen 2002). The species (and clones) used in the present study almost display the same magnitude of differences in their tolerance to high $\mathrm{pH}$. H. triquetra and P. minimum will grow until $\mathrm{pH}$ reaches 9.4 and 9.6, respectively, while C. lineatum will stop growing at $\mathrm{pH}$ of 8.7 . The three species are common in temperate-tropical coastal waters, where they often form red tides. However, C. lineatum forms blooms in more open coastal waters (e.g. the North Sea or the Kattegat/Skagerrak), while the two other species form dense blooms in highly eutrophic fjords (Fenchel et al.1995; Lindholm \& Nummelin 1999). Mixed growth experiments in the laboratory with the three species have shown that the differences in their sensitivity to $\mathrm{pH}$ are large enough to cause a succession of species so that the most $\mathrm{pH}$ tolerant species eventually out-competes the others (Hansen 2002).

The results presented here suggest that both $H$. triquetra and $P$. minimum are able to maintain high rates of carbon fixation at elevated $\mathrm{pH}$ by increasing their affinities for their carbon source $\mathrm{HCO}_{3}^{-}$. Our findings are consistent with the observation that some $\mathrm{HCO}_{3}{ }^{-}$transporters are $\mathrm{CO}_{2}$ induced (Omata et al. 1999). Such a strong response to $\mathrm{pH}$ or $\mathrm{CO}_{2}$ concentrations may be somewhat surprising for an ' $\mathrm{HCO}_{3}{ }^{-}$-user'. It should be considered, however, that at high $\mathrm{pH}$ not only the availability of $\mathrm{CO}_{2}$, but also the concentration of $\mathrm{HCO}_{3}^{-}$, decreases significantly. We also found evidence that the $\mathrm{pH} / \mathrm{CO}_{2}$-dependent responses in dinoflagellates, and possibly in other phytoplankton, may reflect their susceptibility to leakage; in other words, their way to minimize $\mathrm{Ci}$ losses and, hence, save energy. Future investigations should pay more attention to this phenomenon and explore the mechanisms behind reduced leakage in other algae to judge the significance of this process.

\section{ACKNOWLEDGMENTS}

The authors thank Drs Jill Schwarz for the HPLC measurements, Philippe Tortell for discussing various aspects of the 
${ }^{14} \mathrm{C}$-disequilibrium technique and Dieter Sültemeyer for his constructive comments on the manuscript. This research was conducted as part of a German-Israeli Cooperation funded by the Bundesministerium für Bildung und Forschung (BMBF) contract no. 03F0379A. P.J.H was funded by the Danish Natural Research Council project no. 21-03-0449.

\section{REFERENCES}

Badger M.R. \& Price G.D. (1989) Carbonic anhydrase activity associated with the cyanobacterium Synechococcus PCC7942. Plant Physiology 89, 51-60.

Badger M.R., Palmqvist K. \& Yu J.-W. (1994) Measurement of $\mathrm{CO}_{2}$ and $\mathrm{HCO}_{3}^{-}$fluxes in cyanobacteria and microalgae during steady-state photosynthesis. Physiologia Plantarum 90, 529-536.

Badger M.R., Andrews T.J., Whitney S.M., Ludwig M., Yellowlees D.C., Leggat W. \& Price G.D. (1998) The diversity and coevolution of Rubisco, plastids, pyrenoids, and chloroplast-based $\mathrm{CO}_{2}$-concentrating mechanisms in algae. Canadian Journal of Botany 76, 1052-1071.

Beardall J. \& Giordano M. (2002) Ecological implications of microalgal and cyanobacterial $\mathrm{CO}_{2}$ concentrating mechanisms, and their regulation. Functional Plant Biology 29, 335-347.

Berman-Frank I., Kaplan A., Zohary T. \& Dubinsky Z. (1995) Carbonic anhydrase activity in a natural bloom forming dinoflagellates. Journal of Phycology 31, 906-913.

Berman-Frank I., Erez J. \& Kaplan A. (1998) Growth of dinoflagellates as influenced by the availability of $\mathrm{CO}_{2}$ and inorganic carbon uptake in a lake ecosystem. Canadian Journal of Botany 76, 1043-1051.

Burkhardt S., Amoroso G., Riebesell U. \& Sültemeyer D. (2001) $\mathrm{CO}_{2}$ and $\mathrm{HCO}_{3}^{-}$uptake in marine diatoms acclimated to different $\mathrm{CO}_{2}$ concentrations. Limnology and Oceanography 46 (6), 1378-1391.

Caperon J. \& Smith D.F. (1978) Photosynthetic rates of marine algae as a function of inorganic carbon concentration. Limnology and Oceanography 23, 704-708.

Cassar N., Laws E.A., Bidigare R.R. \& Popp B.N. (2004) Bicarbonate uptake by Southern Ocean phytoplankton. Global Biogeochemical Cycles 18, GB2003, doi: 10.1029/ 2003GB002116.

Colman B., Huertas I.E., Bhatti S. \& Dason J.S. (2002) The diversity of inorganic carbon acquisition mechanisms in eukaryotic microalgae. Functional Plant Biology 29, 261-270.

Dason J.S., Huertas I.E. \& Colman B. (2004) Source of inorganic carbon for photosynthesis in two marine dinoflagellates. Journal of Phycology 40, 285-292.

Elzenga J.T.M., Prins H.B.A. \& Stefels J. (2000) The role of extracellular carbonic anhydrase activity in inorganic carbon utilization of Phaeocystis globosa (Prymnesiophyceae): a comparison with other marine algae using the isotope disequilibrium technique. Limnology and Oceanography 45, 372-380.

Espie G.S. \& Colman B. (1986) Inorganic carbon uptake during photosynthesis. I. A theoretical analysis using the isotope disequilibrium technique. Plant Physiology 80, 863-869.

Fenchel T., Bernard C., Esteban G., Finlay B., Hansen P.J. \& Iversen N. (1995) Microbial diversity and activity in a Danish Fjord with anoxic deep water. Ophelia 43, 45-100.

Freeman K.H. \& Hayes J.M. (1992) Fractionation of carbon isotopes by phytoplankton and estimates of ancient $\mathrm{CO}_{2}$ levels. Global Biogeochemical Cycles 6, 185-198.

Giordano M., Beardall J. \& Raven J.A. (2005) $\mathrm{CO}_{2}$ concentrating mechanisms in algae: mechanisms, environmental modulation, and evolution. Annual Review of Plant Biology 56, 99-131.
Goiran C., Al-Moghrabi S., Allemand D. \& Jaubert J. (1996) Inorganic carbon uptake for photosynthesis by the symbiotic coral/ dinoflagellate association. I. Photosynthesis performances of symbionts and dependence on seawater bicarbonate. Journal of Experimental Marine Biology and Ecology 199, 207-225.

Guillard R.R.L. \& Ryther J.H. (1962) Studies of marine planktonic diatoms. Canadian Journal of Microbiology 8, 229-239.

Hansen P.J. (2002) Effect of high pH on the growth and survival of marine phytoplankton: implications for species succession. Aquatic Microbial Ecology 28, 279-288.

Hinga K.R. (2002) Effects of pH on coastal marine phytoplankton. Marine Ecology Progress Series 238, 281-300.

Johnson K.S. (1982) Carbon dioxide hydration and dehydration kinetics in seawater. Limnology and Oceanography 27, 849-855.

Leggat W., Badger M.R. \& Yellowlees D. (1999) Evidence for an inorganic carbon-concentrating mechanism in the symbiotic dinoflagellate Symbiodinium sp. Plant Physiology 121, 12471255.

Lindholm T. \& Nummelin C. (1999) Red tide of the dinoflagellate Heterocapsa triquetra (Dinophyta) in a ferry-mixed coastal inlet. Hydrobiologia 393, 245-251.

Mook W.G. (1986) ${ }^{13} \mathrm{C}$ in atmospheric $\mathrm{CO}_{2}$. Netherlands Journal of Sea Research 20, 211-223.

Nimer N.A., Iglesias-Rodriguez M.D. \& Merrett M.J. (1997) Bicarbonate utilization by marine phytoplankton species. Journal of Phycology 33, 625-631.

Nimer N.A., Brownlee C. \& Merrett M.J. (1999) Extracellular carbonic anhydrase facilitates carbon dioxide availability for photosynthesis in the marine dinoflagellate Prorocentrum micans. Plant Physiology 120, 105-111.

Omata T., Price G.D., Bader M.R., Okamura M., Gohta S. \& Ogawa T. (1999) Identification of an ATP-binding cassette transporter involved in bicarbonate uptake in cyanobacterium Synechococcus sp. strain PCC 7942. Proceedings of the National Academy of Sciences of the USA 96, 13 571-13 756.

Palmqvist K., Yu J.-W. \& Badger M.R. (1994) Carbonic anhydrase activity and inorganic carbon fluxes in low- and high- $\mathrm{C}_{\mathrm{i}}$ cells of Chlamydomonas reinhardtii and Scenedesmus obliquus. Physiologia Plantarum 90, 537-547.

Palmqvist K., Sültemeyer D.F., Baldet P., Andrews T.J. \& Badger M.R. (1995) Characterisation of inorganic carbon fluxes, carbonic anhydrase (s) and ribulose-1,5-bisphosphate carboxylaseoxygenase in the green unicellular alga Coccomyxa. Planta 197, 352-361.

Raven J.A. \& Lucas W.J. (1985) Energy costs of carbon acquisition. In Inorganic Carbon Uptake by Aquatic Photosynthetic Organisms (eds W.J. Lucas \& J.A. Berry), pp. 305-324. The American Society of Plant Physiologists, Rockville, MD, USA.

Raven J.A. \& Johnston A.M. (1991) Mechanisms of inorganiccarbon acquisition in marine phytoplankton and their implications for the use of other resources. Limnology and Oceanography 36, 1701-1714.

Rost B., Riebesell U., Burkhardt S. \& Sültemeyer D. (2003) Carbon acquisition of bloom-forming marine phytoplankton. Limnology and Oceanography 48, 55-67.

Rost B., Riebesell U. \& Sültemeyer D. (2006) Carbon acquisition of marine phytoplankton: effect of the photoperiodic length. Limnology and Oceanography 51, 12-20.

Sharkey T.D. \& Berry J.A. (1985) Carbon isotope fractionation of algae as influenced by an inducible $\mathrm{CO}_{2}$ concentrating mechanism. In Inorganic Carbon Uptake by Aquatic Photosynthetic Organisms (eds W.J. Lucas \& J.A. Berry), pp. 389-401. The American Society of Plant Physiologists, Rockville, MD, USA.

Silvermann D.N. (1982) Carbonic anhydrase. Oxygen-18 exchange catalyzed by an enzyme with rate-contributing proton-transfer steps. Methods in Enzymology 87, 732-752. 
Spalding M.H. \& Portis A.R. (1985) A model of carbon dioxide assimilation in Chlamydomonas reinhardtii. Planta 164, 308-320.

Sültemeyer D. (1998) Carbonic anhydrase in eukaryotic algae: characterization, regulation, and possible function during photosynthesis. Canadian Journal of Botany 76, 962-972.

Thomas W.H. \& Gibson C.H. (1990) Effects of small-scale turbulence on microalgae. Journal of Applied Phycology 2, 71-77.

Tortell P.D. (2000) Evolutionary and ecological perspectives on carbon acquisition in phytoplankton. Limnology and Oceanography 45, 744-750.

Tortell P.D. \& Morel F.M.M. (2002) Sources of inorganic carbon for phytoplankton in the eastern Subtropical and Equatorial Pacific Ocean. Limnology and Oceanography 47, 10121022.

Whitney S.P. \& Andrews J.T. (1998) The $\mathrm{CO}_{2} / \mathrm{O}_{2}$ specificity of single-subunit ribulose-bisphosphate carboxylase from the dinoflagellate Amphidinium carterae. Australian Journal of Plant Physiology 25, 131-138.

Wilbur K.M. \& Anderson N.G. (1948) Electrometric and colorimetric determination of carbonic anhydrase. Journal of Biological Chemistry 176, 147-154.

Zeebe R.E. \& Wolf-Gladrow D.A. (2001) $\mathrm{CO}_{2}$ in Seawater: Equilibrium, Kinetics, Isotopes. Elsevier Oceanography Book Series 65. Elsevier: Amsterdam, the Netherlands.

Zhang J., Quay P.D. \& Wilbur D.O. (1995) Carbon isotope fractionation during gas-water exchange and dissolution of $\mathrm{CO}_{2}$. Geochimica et Cosmochimica. Acta 59, 107-114.

Received 17 June 2005; received in revised form 31 August 2005; accepted for publication 2 September 2005 